\title{
«PARA DECIR LA PALABRA $Y O »$ : UNA REFLEXIÓN SOBRE LA SUBJETIVIDAD EN LA OBRA DE JOSÉ ÁNGEL VALENTE
}

\author{
MANUEl FERnÁNDEZ CASANOVA \\ Universitat de Barcelona \\ A Noemí Montetes-Mairal
}

Para decir la palabra yo hemos de saber decirla como en ausencia de quien la enuncia.

(De un libro)

\section{RESUMEN}

En el presente ensayo analizaremos el alcance de la llamada cuestión del sujeto dentro de la obra de José Ángel Valente. Partiendo de una definición de la subjetividad en clave de trasunto de la consciencia, de instancia permanente enfrentada a una realidad en constante cambio, observaremos el rechazo que el escritor experimenta ante tal concepción, así como el modo en que sus textos plantean el conflicto y buscan una resolución al mismo. Nuestro análisis atenderá fundamentalmente a tres niveles: tratamiento que recibe el yo lírico en esta obra, relación que se establece en ella entre el hombre y la realidad, y reformulación del concepto de autoría; y nos llevará desde unas primeras maniobras de desubjetivización irónica (deudoras por igual de una percepción angustiosa de la existencia y de la necesidad de abordar lo subjetivo desde el compromiso con el colectivo) hasta la adopción por parte del escritor de un enfoque místico de la cuestión en el que las figuras de la nada y de la alteridad tendrán un papel decisivo.

Palabras clave: Subjetividad, Mística, Nada, Alteridad.

\section{«TO SAY THE WORD I»: \\ A REFLECTION ON THE SUBJECTIVITY IN JOSÉ ÁNGEL VALENTE WORKS}

\begin{abstract}
The so-called Question on the subject in José Ángel Valente's Works is going to be analysed in this essay. This essay is been thought from the writer's reject to the definition of subjectivity as a representation of the consciousness, as a permanent request opposed to an ever-changing Reality. From this point, we'll be able to see how at the same time his texts pose this conflict and look for the solution. This analyse will start from the following three levels: the treatment given to the lyrical self, the relationship between man and Reality, and the reformulation of the concept of authorship. This will take us from the first manoeuvres of
\end{abstract}


ironical desubjectivation - in debt with an anguished perception of the existence as with to the necessity of treating the subjectivity from the compromise with the collective - to the writer's assumption of a mystical focussing on this question, a question in which Nothingness and Otherness will play a decisive role.

Key words: Valente, Subjectivity, Mystical, Nothingness, Otherness.

A lo largo del último siglo y medio, pocas temáticas han tenido un papel tan crucial en las reflexiones filosóficas nacidas en Occidente como la llamada cuestión del sujeto; una problemática que se ha presentado con frecuencia asociada a la visión crítica de la modernidad fundada por dicho sujeto, y a la falta de confianza en la razón como método de acceso a la realidad y conocimiento de esta (una desconfianza asimismo extensible a los principios lógicos de identidad, no contradicción y tercero excluido).

Precisamente estos van a ser los parámetros por los que va a transcurrir y desarrollarse nuestro análisis. Si bien, antes de empezar, resulta imprescindible esclarecer y establecer el alcance y la naturaleza de ese sujeto sobre cuya crisis vamos a especular. De las diversas opciones posibles me ha parecido conveniente optar, de acuerdo a lo que en el fondo es el tema central de este ensayo (la reflexión sobre la subjetividad que se desprende de la obra de José Ángel Valente), por aquella configuración que, heredera del cartesianismo, identifica al sujeto con la consciencia; un sujeto que, de acuerdo a la separación que el filósofo francés estableciera entre res cogitans y res extensa, deberemos considerar en términos de interioridad opuesta a la exterioridad del objeto (es decir, el yo como única instancia permanente, enfrentado a una realidad en constante cambio) y en el que asimismo se opera la quiebra irreconciliable entre mente y cuerpo.

La genealogía de la crisis de la subjetividad nos conduce al último tercio del siglo XIX y principios del XX, período en el que se formulan las primeras objeciones al respecto de la conveniencia de seguir otorgando al sujeto el papel protagonista en la aventura del conocimiento. Anotemos que, a grandes trazos, las dudas se orientaron bien a considerar el sujeto como máscara o narración de corte autobiográfico, bien a destacar su dependencia de alguna instancia superior (fuera el ser, la historia, la estructura socio económica o el inconsciente), o bien ahondando en su carácter escindido. Estas propuestas fueron vividas por todo el pensamiento de la época con un agudo sentimiento de zozobra, dada la circunstancia, apuntada por Gadamer, de que, después de ellas, «no se pueden tomar ingenuamente los hechos de la conciencia por hechos de la realidad» 1 .

No será hasta el último tercio del siglo XX (después de una primera reivindicación de un sujeto entendido desde el ámbito de su existencia singu-

${ }^{1}$ Gadamer, H.G., «Subjetividad e intersubjetividad, sujeto y persona», El giro hermenéutico, Madrid, Cátedra, 2001, p. 16. 
lar, y por tanto ajeno a la abstracción propia del sujeto trascendental de la filosofía idealista), cuando la 'cuestión' deje de ser definitivamente considerada en términos de crisis del pensamiento occidental y los filósofos hablen abiertamente del olvido o superación de la subjetividad desde una actitud afirmativa. Y si bien las escuelas estructuralista, posestructuralista y hermenéutica, con su interpretación del problema a partir de parámetros linguiísticos, tuvieron una gran responsabilidad en ello, también ayudó la propia constatación, por parte de ese sujeto nacido para dominar el mundo mediante su fe en la razón y el progreso, de la alineación y la reificación a la que, con el cumplimiento de la utopía tecnológica (es decir, del destino impuesto por su mismo afán totalizador), se había visto finalmente condenado.

Pero ¿y en el ámbito de nuestra incumbencia? ¿Encuentra eco en la literatura de la misma época esta meditación sobre la subjetividad? La respuesta no sólo ha de ser afirmativa, sino que debería señalar que fue precisamente desde la literatura donde se plantearon las primeras objeciones ante el cariz que tomaba el desarrollo de la modernidad, el creciente peso de la racionalidad científica y, por supuesto, el primado del sujeto. Y si bien la estética romántica, la primera en dudar, acabaría privilegiando los aspectos más solipsistas a los más críticos, contribuyendo así desde lo literario a esa primacía del yo, aquellos reparos iniciales encontrarán eco posterior en los escritos de poetas como Rimbaud o Mallarmé. Así, mientras Rimbaud ubica su yo en el otro en las Lettres au voyant ${ }^{2}$, Mallarmé, que según propia confesión epistolar no fue ajeno al abismo de la nada, se adelanta unas cuantas décadas al giro lingüístico operado por la filosofía, y aboga por la disolución del yo en beneficio del lenguaje como paso previo a la creación poética: «L'oeuvre pure implique la disparition élocutoire du poéte, qui céde l'initiative aux mots». Ya en nuestro entorno geográfico, con la llegada del siglo XX, la crítica de la subjetividad se refleja con notable lucidez en los heterónimos de F. Pessoa o los apócrifos de A. Machado; una crítica que asimismo, algunas décadas más tarde, como no podía ser de otra manera dada su forma de entender la poesía como experiencia hermana de la filosofía, ocuparía un espacio destacado en la obra de José Ángel Valente, ya fuera en los aspectos referentes al yo literario, al estatuto del autor o a la forma de afrontar la relación que el hombre establece con la realidad a través del lenguaje, asuntos todos que serán objeto de análisis en este ensayo.

De hecho, ya en su primer poemario publicado, A modo de esperanza (1955), Valente nos ofrece una primera muestra de su proverbial incomodidad frente al recurso al yo lírico. Así, a lo largo de todo el poemario, presidido por la idea de la muerte, se hace evidente la naturaleza desrealizada

2 'Je est un autre'; 'on me pense'; 'car il arrive à l'inconnu!'. Estas tres escuetas proposiciones pertenecientes a las Lettres au voyant resumen por sí solas gran parte de las búsquedas literarias del último siglo y medio. 
de un yo que frente a tamaña realidad ineludible es incapaz de reconocerse en ninguno de los signos en los que suele descansar la propia identidad: el rostro («Hoy he visto mi rostro tan ajeno [...] / y ¿dónde estoy —me digo/ y quién me mira / desde este rostro, máscara de nadie?» — «El espejo», 2006: 71-), el nombre, el recuerdo de la infancia o la identificación con los familiares desaparecidos. Y sin embargo, en esa poetización del encuentro del hombre con su condición de 'ser-para-la-muerte' que es $A$ modo de esperanza, ese ser 'emplazado a vivir', que en algunos poemas («Destrucción del solitario») parece desear la muerte, y que en otros se rebela contra la fatalidad («dime que soy verdad, / que estoy en pie, que es cierto / el aire, que no puedo / morir» — «Como la muerte», l. c.: 89-), acaba por encontrar una salida a la angustia existencial, un hálito de esperanza, que guarda relación con dos actitudes posibles: la primera, implícita en el poema con que finaliza el libro, «De vida y muerte», en el que el poeta apuesta con íntimo y humilde heroísmo por aceptar dicha condición, por simplemente ser para «morir de cara», «morir / de haber vivido» $($. c c.: 101); la segunda (rastreable ya desde «Serán ceniza», primer poema del libro), el saber que no está solo, que es uno entre otros, que forma parte de un colectivo, que más allá del yo, se ubica el otro.

Dos años más tarde de la publicación de A modo de esperanza, en 1957, ve la luz el artículo «Juan Ramón Jiménez en la tradición poética del medio siglo» (luego recogido en Las palabras de la tribu, 1971), en donde Valente contrapone el pensamiento de Juan Ramón al de A. Machado. Concretamente, centra su análisis en el tratamiento que las figuras del yo y de la alteridad reciben en ambos escritores. Al inicio del artículo, Valente resume la idea de Machado con la 'abelmartiniana' fórmula de «teoría de la esencial heterogeneidad del $\operatorname{ser}^{3}$ », que opone a la «teoría antípoda de la esencial homogeneidad del yo» (2002a: 85), con la que identifica el pensamiento de Jiménez. Valente suscribe las palabras del primero al respecto de cuál debe ser la misión esencial de la poesía: «No es el yo fundamental / eso que busca el

${ }^{3}$ Formulación machadiana procedente del Juan de Mairena que ya había atraído al O. Paz de El laberinto de la soledad (1950), tal como podemos constatar desde su mismo epígrafe, y a la que volvería, con posterioridad, en las diversas ediciones de El arco y la lira. Así, mientras en la primera (México D. F., F. C. E., 1956, p. 91), en su comentario de la obra del poeta sevillano (centrado especialmente en el desajuste que observa Paz entre la prosa y la poesía de Machado al respecto de la aparición del 'otro' -imperceptible en esta última, según aquel一), se afirma: «si el acto poético es algo, es revelación del ser y, por eso mismo, erotismo, impulso amoroso, ruptura del ser, "otredad"» (pp. 8687), en la segunda (México D. F., F. C. E., 1967), se refrenda este 'descubrimiento' o 'intuición capital' con estas otras palabras: «la poesía, si es algo, es revelación de la "esencial heterogeneidad del ser", erotismo, "otredad"» (p. 91). Recordemos, asimismo, que en una y otra edición, Paz adjudica a esta otredad un carácter de rememoración de nuestra identidad perdida, en el transcurso de la cual «aparece, emerge, ese "otro" que somos» (1956, p. 132; 1967, p. 137). 
poeta, / sino el tú esencial» (ibid.), al tiempo que ubica al segundo en la estirpe de la poesía romántica de exaltación radical del yo. Para Valente, Juan Ramón incorpora las formas de la poesía mística, pero sin entrar en el fondo, pues una de las piedras angulares de la experiencia mística, la salida al exterior hacia Dios o éxtasis, guarda en el poeta de Moguer (según el autor del artículo) un mero carácter especular: «Estamos aquí ante muy otra aventura del alma. Se trata de un viaje inmóvil que comienza en el poeta, pasa por el poeta y termina en el poeta» $($. c c.: 90). De ahí que concluya definiendo la poesía de Jiménez como «una melancólica conversación acerca de él mismo» en la que «todo movimiento de alteridad es, en rigor, imposible» $(l . c .: 89)^{4}$.

Se trata de un artículo que, como gran parte de los escritos por Valente, debemos leer en clave personal e incluso programática. El poeta establece su horizonte poético, la creación de una poesía capaz de atisbar «otras realidades, sobre todo la posibilidad de la real existencia del prójimo» (l. c.: 92). Algunos de los versos de Poemas a Lázaro (1960), su segundo poemario, resultan reveladores al respecto. Así, en «Primer poema» se afirma: «Poeta, oh no, / sujeto de una vieja impudicia: / mi historia debe ser olvidada, / mezclada en la suma total / que la hará verdadera» (2006: 107); porque sólo desde el anonimato de lo colectivo, el canto puede ser poder. Así, en otra composición, «La plaza», se contrapone la soledad actual del lugar a ese otro momento en que en él «latía un solo corazón unánime» (l. c.: 146), el formado por los «hombres unidos / en la misma esperanza» (ibid.). Y si bien el tono elegíaco y la añoranza son perceptibles en algunos instantes del poemario, también queda patente en él la apuesta del poeta por el compromiso, porque: «Ésta es la hora, éste es el tiempo / — hijo soy de esta historia—》 («Sobre el lugar del canto», l. c.: 150).

Una perspectiva complementaria de la anterior es la que nos ofrece un artículo fechado en 1963, «La necesidad y la musa», en el que Valente rea-

\footnotetext{
${ }^{4}$ «todo movimiento de alteridad, en un sentido último, es imposible», si atendemos al texto original aparecido en Índice. Es notoria la tendenciosidad de las opiniones sobre la obra de J. R. Jiménez del Valente de entonces, en lo que visto desde hoy se configura casi como una constante de época. Algunos años más tarde, en 1971, P. Gimferrer, en su ensayo panorámico «Notas parciales sobre poesía española de posguerra» (recogido en la edición ampliada de Gimferrer, P., Radicalidades, Barcelona, Península, 2000), se hace eco de la sucesiva apropiación «con júbilo totémico» por parte de las principales escuelas de la posguerra del «consabido fetiche machadiano». Y prosigue: «Este estado de opinión imponía, no sólo un rechazo de "lo que no debe hacerse" [...] sino también una determinada lectura de los autores existentes. [...] el Juan Ramón de Espacio o de Dios deseado $y$ deseante o de Españoles de tres mundos era relegado al gueto en beneficio de Platero y yo» (l. c.: 199-200). Y si bien esta última no fue precisamente la actitud con la que Valente afrontó la lectura de la obra juanramoniana, siendo asimismo indiscutible la hondura intelectual desde la que se aproximó a la obra de Machado, también es cierto que sería el propio Valente quien, a lo largo de los años, iría reconociendo lo desacertado de su visión inicial de Jiménez.
} 
liza unas reflexiones acerca del arte y la literatura contemporáneos, que, más allá de adolecer de una cierta estrechez panorámica, nos dan buena medida de su concepción por entonces de lo subjetivo. Así, el escritor resume la historia literaria del siglo XX como la constatación de la quiebra entre la experiencia personal y la colectiva. Y prosigue:

El fin de etapa de las plataformas sociales [...] ha encontrado su manifestación literaria en formas exasperadas de expresión de la subjetividad, de lo patológico, del absurdo, de la inmovilidad de la condición humana, en la sustitución de un universo de seres próximos o prójimos por un universo de individuos adyacentes o contiguos clausurados en su experiencia personal y en la mitificación, por último, de la incomunicabilidad de esa experiencia. Tales son, en efecto, los temas alrededor de los cuales ciertas formas de vida agonizantes se han manifestado en las obras de Kafka, Musil, Faulkner, Camus o Beckett (2002a: 137).

Para Valente, este horizonte muestra su peor cara en la poesía:

Es probable que entre todas las formas contemporáneas del arte sea la poesía la que más se haya agotado en la exploración solitaria de la experiencia personal, con riesgo claro de perderse en el laberinto de las mitologías privadas incapaces de una representación coherente de la realidad. En ese sentido, quizá haya contribuido la poesía más que ningún otro arte a la fragmentación de lenguajes que padece el hombre contemporáneo, traicionando así lo que es sin duda parte esencial de su misión: la creación de un lenguaje común. Falta de ese lenguaje, parcialmente consumida en formas histéricas de mandarinismo o pseudosacralización, la poesía quedaba especialmente incapacitada para la construcción de nuevos mitos colectivos (l. c.: 138-139).

En un párrafo posterior Valente, para el que la singularidad y la soledad acabarían siendo verdadera fuente de subversión (valga la conocida formulación de Jabès) ${ }^{5}$, aclara que no se trata tanto de postergar las formas de expresión de la experiencia privada, como de ensanchar estas «en busca de nuevos contenidos de signo colectivo» $(l$. c.: 139). Sólo así podrá cumplirse una vez más «la misión de toda gran poesía: la conversión de la experiencia solitaria en experiencia solidaria» (ibid.).

Pero además, la obra ensayística de A. Machado, más allá de posibilitar a Valente el acceso a una subjetividad de naturaleza colectiva, también le ayudará a modelar los perfiles de esa incomodidad frente a la instancia del sujeto antes mencionada. Así, nuestro escritor, fija su atención en la macha-

${ }^{5}$ De hecho, es de rigor anotar que la soledad ya se había constituido con cierta anterioridad como un valor cardinal para Valente, al menos si tenemos en cuenta el siguiente fragmento correspondiente a «Nuevos maestros»: «Frente a los embaucadores, frente a los vocingleros, su primera lección, la lección de su mudo ejemplo, es ésta: silencio interior, soledad con Dios — esta soledad nunca puede ser egoísta-, donde se realice absolutamente la Verdad» (1949:5). Por otra parte, a ningún lector avisado se le deberían escapar ni la mención a los vocingleros, ni al silencio o a la calidad interior del mismo, ni a lo divino, ni esa evidente preocupación del escritor por no caer en una postura egoísta, aspectos todos con los que de una u otra manera nos volveremos a encontrar en este ensayo. 
diana formulación de la 'otredad de lo uno'. Son palabras de Los complementarios recogidas en «Machado y sus apócrifos»:

nuestro espíritu contiene elementos para la construcción de muchas personalidades, todas ellas tan ricas, coherentes y acabadas como aquella - elegida o impuesta- que se llama nuestro carácter. Lo que se suele entender por personalidad no es sino el supuesto personaje que a lo largo del tiempo parece llevar la voz cantante. Pero este personaje, ¿está a cargo siempre del mismo actor? (l. c.: 95-96).

Cualquier poeta que se adscriba a semejante configuración de la subjetividad se aleja sin duda de tentación totalizadora alguna. Pero, además, queda capacitado para poder acceder a la realidad de un modo verdadero, 'heterogeneizante', 'inventor'. Valente, siguiendo a Machado, se inscribe en aquella corriente con origen en el romanticismo alemán que ubica en la ironía no sólo el fundamento de dicha operación creadora, sino el de una manera crítica y alternativa de entender la subjetividad:

La ironía es un movimiento de participación que complica al creador en las mismas leyes de la realidad que reconoce. El recinto de lo subjetivo queda abierto, se destruye en cierto modo al reconocerse como tal y da paso a ese proceso de autocorrección de la fragilidad [...]. La ironía es un atisbarse o verse de lo uno, que toma así distancias de sí mismo y se descubre diversificable, alterable. Los apócrifos de Machado nacen de ese movimiento diversificador y participante de la ironía que corrige sin cesar lo «auténtico», la apariencia pública de la realidad para poder inventarla o descubrirla. Por eso la ironía es engendradora de misterio y de sutiles intermediarios que tienden redes a la falsedad de lo «auténtico» (l. c.: 96).

Desde el inicio de su trayectoria, Valente incluyó en sus poemarios diversas formulaciones de carácter irónico, a las que retornaría una y otra vez. Tal vez la más característica sea la utilización del doble, unas veces visto como imposibilidad del reconocimiento de uno mismo frente a su imagen en el espejo (el ya citado «El espejo», de $A$ modo de esperanza; o «El autor en su treinta aniversario», de La memoria y los signos); otras, presente en la fórmula de combate con el otro («Cuando en las noches», de La memoria y los signos); o bien como convocatoria de lo fantasmagórico («El puente», de La memoria y los signos); o, finalmente, en su variante de desdoblamiento en un yo presente y su pasado («Son los ríos», de Poemas a Lázaro; o «Calles de Cambridge, 1974», de Interior con figuras), desarrollo particularmente interesante por lo que de recusación tiene a uno de los fundamentos de la subjetividad, la percepción de uno mismo como continuidad en el tiempo. En todas estas maniobras de distanciamiento del sujeto lírico de sí mismo, me parece entrever la búsqueda por parte del autor de una posibilidad de existencia auténtica en el sentido heideggeriano. Tal como podremos comprobar más adelante, tan sólo podrá hallarla una vez el yo sea consciente de 
lo que en realidad le ofrece el espejo: la imposibilidad de todo autorreconocimiento más allá de la nada ${ }^{6}$.

Pero, además, la ironía, tal como hemos apuntado, es uno de los medios de los que se vale la experiencia poética para alcanzar un más profundo conocimiento de la realidad, misión esta que Valente nunca dejó de reivindicar para la poesía. Así, en «Conocimiento y comunicación» (artículo de 1957, si bien publicado por primera vez en 1963 dentro de la antología de F. Ribes Poesía última ${ }^{7}$, el escritor atiende a la relación que se establece entre el hombre y la realidad circundante. La apabullante riqueza de esta, así como la circunstancia de nuestra inmersión en ella, hacen imposible cualquier intento de aprehensión de la propia experiencia: «hay algo que queda siempre oculto u ocultado en la experiencia inmediata» (2002a: 21), afirma Valente, que luego formula lo que él mismo define como ley de necesidad: «hay una cara de la experiencia [...] que no puede ser conocida más que poéticamente» $(l . c .: 24)^{8}$. Para el escritor, las ciencias, que basan su saber en el análisis y en la elaboración de universales, se muestran insuficientes a la hora de describir lo que de fugaz, único e irrepetible tienen algunas experiencias, mientras que la poesía, que hace de la realidad «centro y destino único del acto creador» («Tendencia y estilo», $l$. c.: 29), sí es

\footnotetext{
${ }^{6}$ En «Para una imagen rota», de Interior con figuras, Valente plasma este tránsito de una concepción negativa de lo especular a otra más afirmativa, correlato, tal como veremos más adelante, del tránsito de una concepción de lo humano en clave existencial a otra de perfil ontológico: «Absurdo / con los gestos de ayer, vestido de otro tiempo / vagamente difunto // [...] El tiempo arrasa cada vez la vida. / El tiempo incendia cada vez la vida. // No vuelvas pues, no vuelvas con tu imagen, / con tu perpetua o pertinaz imagen, / que de ti mismo aquí te destituye. // Mira al vacío en su plenario rostro. / Míralo sin llanto, / como quien ha sabido conjurar la muerte, / salvar así de su feroz naufragio / la irrenunciable juventud» (2006: 344). En otro orden de cosas, al respecto de esta cuestión, me parece interesante recordar el notable parecido observado por J. E. Cirlot entre las formas hebreas Ain (nada) y Ani (yo) (CIRLOT, J.E., Diccionario de símbolos, Barcelona, Labor, 1982, p. 321).

${ }^{7}$ Ribes, F. (ed), Poesía última, Madrid, Taurus, 1963.

${ }^{8}$ Desde luego, conviene no olvidar el contexto histórico-literario en el que surge esta reivindicación, que es el de la España que sale de la posguerra, y el del enconado debate entre partidarios y detractores de aquella formulación de la poesía como comunicación. Con «Conocimiento y comunicación», Valente, de algún modo, se alineaba con las posturas de C. Barral y J. Gil de Biedma frente a los poetas sociales, si bien desde puntos de partida e intereses bien diferentes. Valente reconoció la necesidad y oportunidad de la temática social (incluso en alguna ocasión se consideró también poeta social o cuando menos solidario, si bien siempre con matices), así como la justicia de sus postulados, aunque nunca aceptó que el poeta, en aras de una mayor recepción, debiera renunciar a la indagación en la palabra, o lo que viene a ser lo mismo, se viera forzado a privilegiar la tendencia por encima del estilo (al respecto, también en Poesía última — «Unas notas sobre poesía», p. 91-, sentencia Claudio Rodríguez: «Se cree que un tema justo o positivo es una especie de pasaporte de autenticidad poética, sin más. Cuántos temas justos y cuántos poemas injustos»).
} 
capaz de asumir esa viaje a lo desconocido. (En «El don», un artículo de 1996 recogido en La experiencia abisal, Valente lleva esta distinción entre el conocimiento científico y el poético al territorio de sus respectivos lenguajes. Así, distinguirá entre formas de la discursividad, caracterizadas por enunciar verdades predeterminadas, y formas de la intuición, alumbradoras de verdades hasta entonces desconocidas. Es precisamente a través de estas formas como la poesía vence las limitaciones inherentes al lenguaje discursivo y puede acceder a la expresión de lo inefable, de la experiencia inmediata, a todo ese material simbólico «no sujeto al pensamiento proposicional y a la "sintaxis lógica del lenguaje"» (2004: 167) que nos abre la posibilidad de una gnoseología de raíz no positivista) ${ }^{9}$.

Queda así desvelado uno de los presupuestos fundamentales de esta forma de concebir la experiencia poética, el que afirma que el conocimiento al que se accede a través de esta no puede anteceder al proceso de creación del poema. No en vano (y son formulaciones recogidas por extenso en los estudios valentianos) el poema es un «movimiento de indagación y tanteo», de «sondeo en lo oscuro», un «conocimiento "haciéndose"» (2002a: 22), alumbramiento, revelación o manifestación en el logos de lo encubierto, lo desconocido ${ }^{10}$. Por todo ello, es incompatible con todo condicionamiento previo de sentido, y si lo hubiere, este debe ser destruido ${ }^{11}$. Valente volvería a esta reflexión en un artículo de 1982, «Las condiciones del pájaro solitario», donde enuncia las condiciones ineludibles para la manifestación de la forma poética, que sucede a través de dos disoluciones: la ya mencionada de una significación predeterminada y la de toda referencia a hombre o autor — que analizaremos más adelante-. Así, sólo despojándose de instrumentalidad ( «En efecto, lo poético exige como requisito primero el descondicionamiento del lenguaje como instrumentalidad. El lenguaje concebido como sola instrumentalidad deja de participar en la palabra», afirmará el poeta en «Sobre la operación de las palabras sustanciales», 2000a: 61) e intenciona-

9 A pesar de la lejanía de la fecha de aparición de este artículo con respecto a la época en la que nos encontramos en la argumentación principal, me parece pertinente la referencia al mismo, teniendo en cuenta que Valente, cuyo planteamiento sigue de cerca las teorías de Susan K. Langer, reconoce en él la relación existente entre los trabajos de esta y los artículos incluidos en Las palabras de la tribu.

${ }^{10}$ Creo importante mencionar al respecto esa otra definición del poema como "forma aparicional del conocer» (2002a: 20n), añadida por el escritor a «Conocimiento y comunicación» en la reedición de 1994 de Las palabras de la tribu, y prueba del creciente influjo que la obra de P. Celan había ido adquiriendo en la de Valente.

${ }^{11}$ En «Crónica II, 1968» (El inocente), versión de un fragmento de Artaud, se califica de «cerdos» a «todos los que dominan su lenguaje, todos aquellos para quienes tienen las palabras sentido» (2006: 309). A. Sánchez Robayna, en «Sobre dos poemas de José Ángel Valente», en VV. AA., En torno a la obra de José Ángel Valente, Madrid, Alianza, 1996, pp. 41-46, nos advierte de que precisamente dicho improperio es el único añadido de Valente al texto original. 
lidad algunas ( «El artista tiene que estar desorientado, la intencionalidad liquida de raíz el impulso creador» — «El arte como vacío», 2002: 121—), puede el lenguaje poético (de acuerdo a la especulación valentiana) posibilitar nuestro acceso a los más remotos ámbitos de la experiencia.

Es precisamente a través de esta concepción del poema ajena a condicionamientos predeterminados desde la que debemos abordar el análisis del compromiso ético presente en la obra de nuestro poeta. Porque conviene aclarar que la desconfianza en la figura del sujeto como agente del conocimiento, unida al hecho de que el poeta mantenga como compromiso primordial, antes que ningún otro, aquel que guarda para con el lenguaje ${ }^{12}$, no tienen por qué comportar una poesía que dé la callada por respuesta a las cuestiones que angustian a la humanidad, de tal modo que el deseo de Luis Cernuda de que la obra poética sea «resultado de una experiencia espiritual, externamente estética, pero internamente ética» (2002a: 122), es también aplicable a la creación valentiana.

Esta actitud ética se resuelve, en primer lugar, en ese 'uno entre otros' ya mencionado, en el que los perfiles del desarraigo y el abrazo esperanzado a quien se ve prisionero del propio existir, se juntan al compromiso solidario con las víctimas inocentes de la Historia. Ambos aspectos se presentan aglutinados en los poemas y prosas en los que la asfixiante vivencia de la posguerra se une a la denuncia de la dictadura franquista, y por ende de todo régimen que haga de la represión y la violencia su modus operandi natural. Un ejemplo paradigmático al respecto lo tenemos en los textos que conforman El fin de la edad de plata (1973), volumen en prosa en la que la temática comprometida se presenta con una concentración nunca luego superada y que ha hecho afirmar a la crítica su carácter de 'fin del trabajo del luto' (J. Ancet) o 'ajuste de cuentas' (F. García Lara). Asimismo, desde un enfoque cercano, merecen nuestra atención los poemas contenidos en la sección VI de La memoria y los signos (1966), que conforman una lúcida reflexión sobre la pervivencia, la dimensión ética y el papel de la palabra y su poeta en un 'tiempo de miseria' ${ }^{13}$.

12 En esta cuestión, Valente no se distancia en exceso de O. Paz, para quien la moral del escritor, más que en los temas o en los propósitos (es decir, la intencionalidad), residía en su conducta frente al lenguaje. Tengamos en cuenta, asimismo, que para nuestro escritor, el compromiso con el lenguaje no es sino un compromiso con la libertad, tal como queda claro a tenor de la siguiente respuesta: «El mío es el compromiso con la palabra poética, que te obliga contra tu voluntad a decir lo que tal vez tú no quieres decir, porque es una palabra profundamente libre. Esa palabra tiene más fuerza que tú» (2000: 135).

13 Este 'uno entre otros' (materialización poética de lo que más adelante daremos en llamar 'descenso a la memoria colectiva'), con la entrada en los ochenta, prácticamente desaparece de la producción valentiana (serían notable excepción los poemas dedicados a la memoria de las víctimas de la Guerra Civil, del Holocausto o del horror atómico). Es evidente que la nueva orientación ontológica que tomará esta poesía — que complicará el encaje de temáticas comprometidas con un tiempo y un lugar concretos-, así como pro- 
De hecho, hacia finales de los sesenta este compromiso ético se empezará a orientar de forma paulatina hacia lo lingüístico, circunstancia esta que podemos contemplar como una consecuencia natural de la profundización del escritor en el análisis de los medios empleados por el poder para imponer su orden; uno de estos instrumentos es la ideología, a la que Valente concede un papel fundamental en el enmascaramiento y secuestro de la realidad, escenario indispensable para que el poder pueda desenvolverse con impunidad, y en el que la ideología nos atrapa mediante una operación de progresiva corrupción del lenguaje, lo que para Valente hace de ella la más importante enemiga de todo cuanto pugna por manifestarse o ser a través de la palabra verdadera (es decir, de aquello que constituye la materia de la poesía). Así, sin perder de vista lo anterior, y ya dentro del ámbito de la creación, el poeta aboga por acometer dos ejercicios previos a la misma, uno de desactivación de esa falsa visión de la realidad impuesta por la ideología, y otro por el cual el lenguaje es despojado de toda adulteración de signo ideológico. «Sólo la palabra poética, que por el hecho de ser creadora lleva en su raíz la denuncia, restituye al lenguaje su verdad» (2002a: 57), se afirma en «Ideología y lenguaje». Y precisamente esta pasa entonces a ser para Valente la principal misión del poeta, su verdadera función social, expresada a través de la célebre formulación de Mallarmé: «la restauración de un lenguaje comunitario deteriorado o corrupto, es decir, la posibilidad histórica de 'dar un sentido más puro a las palabras de la tribu'» (ibid $)^{14}$.

\footnotetext{
bablemente aquello que se dio en denominar el 'desencanto de las ideologías', tuvieron un gran papel en este cambio, que no afectará a los contenidos de sus entrevistas ni de sus colaboraciones periodísticas. Valente siempre tuvo presente la facilidad con la que todo compromiso acaba derivando en ortodoxia o directamente intolerancia, y en general, hacia el final de su trayectoria, prefirió centrar su mensaje en reivindicar el estatuto del individuo en la sociedad globalizada. Es en este contexto en el debemos situar el siguiente fragmento: «La sociedad ha de realizarse en el individuo más que el individuo en la sociedad, respecto de la cual puede a veces — cada vez menos - estar a contracorriente. El movimiento inverso genera el "individualismo de masa" y bloquea —en la totalidad del sistema único o aldea mundial- la realización del individuo-sujeto, del individuo-persona» («A propósito del vacío, la forma y la quietud», 1997: 28).

${ }^{14}$ Este afán de redimir el lenguaje de toda manipulación ideológica, ya sea mediante un proceso de depuración o de voladura, es el mismo que late en un escrito un poco anterior a los citados, «Examen de conciencia», en donde Juan Goytisolo (particularizando la cuestión en nuestras letras) expresa la necesidad de una crítica e impugnación de las palabras sagradas de la 'rancia prosa castellanista' como paso previo fundamental para la destrucción de la mitología y los valores expresados a través de ellas por la derecha (GoYTISOlO, J., «Examen de conciencia», El furgón de cola, París, Ruedo Ibérico, 1967, p. 183). En otro orden de cosas, con posterioridad (concretamente en «Cuatro referentes para una estética contemporánea» -Elogio del calígrafo-), Valente actualizaría su crítica, esta vez dirigida a la tecnología y a los medios de información, en tanto que realidades hostiles a la palabra (una circunstancia ya apreciada por Heidegger y Mallarmé, respectivamente).
} 
Este proceso de depuración lingüística tiene especial relevancia en los libros escritos en el tránsito de los sesenta a los setenta, siendo tal vez el mejor ejemplo al respecto Presentación y memorial para un monumento (1970), donde Valente se vale de la parodia para desenmascarar los clichés de los que de forma subrepticia se vale el poder para aniquilar la especificidad del ser humano. En libros posteriores, el escritor avanza en este proceso, al final del cual habrá conseguido llevar al lenguaje al punto cero «de la indeterminación infinita, de la infinita libertad» (2006: 65) pretendido. Un libro capital en este trayecto será, ya desde su misma concepción, Treinta y siete fragmentos ${ }^{15}$, no sólo por lo que supone de expresión de lo residual y de negación de lo absoluto, sino también de superación de una concepción del lenguaje en la que el yo se erige en función gramatical protagonista.

De hecho, el giro que iba a conducir a la obra valentiana a la 'desaparición elocutoria del yo' tiene su momento inaugural en 1970 con una intuición en bruto, la que se refleja en «Biografía sumaria», poema con el que se abre El inocente (1970): «Hizo tres ejercicios / de disolución de sí mismo / y al cuarto quedó solo / con la mirada fija en la respuesta / que nadie pudo darle» (l. c.: 281). Y si ya de por sí, tal como afirma A. Sánchez Robayna, «el "yo" es una perspectiva mascararia que, en la empresa del conocimiento, no puede operar sino como una reducción o un relativismo» ${ }^{16}$, tampoco mejora esta apreciación el hecho de que este yo se sepa atravesado y finalmente constituido por un lenguaje que yace preso en poder de la ideología ${ }^{17}$. De ahí que, volviendo a El fin de la edad de plata, y concretamente a los relatos construidos en los aledaños de la experiencia biográfica del autor, más allá de la crítica del tiempo gris de la posguerra, me parezca observar en esa maniobra de desfiguración de la propia memoria que los caracteriza, la invitación a una lectura de los acontecimientos relatados en clave de crónica de la disolución de ese sujeto alienado de cuya necedad intolerante es mejor mantenerse en guardia. Valga como muestra este fragmento de «De la no consolación de la memoria»: «No guardaba del lugar donde nació recuerdo grato alguno. Le habría gustado, me explicaba, nacer en ningún sitio para que en él pusieran sobre piedra solemne escrito en humo: AQUÍ NO NACIÓ NADIE» (2006: 733).

Finalmente podemos afirmar que hacia mediados de los setenta la poética valentiana ha conseguido alcanzar el punto o grado cero de lo subjetivo. No en vano, en Interior con figuras (1976), el yo observa impávido como se desdibujan paulatinamente los contornos de su identidad. De ahí que a

\footnotetext{
${ }^{15}$ Libro escrito en 1971 y publicado por primera vez en 1972 dentro de la primera edición de Punto cero.

16 «Pensamiento y figuras de José Ángel Valente», en SÁnCheZ RobAYnA, A., $L a$ sombra del mundo, Valencia, Pre-textos, 1999, p. 140.

17 Ya en «Primer poema», de Poemas a Lázaro, el poeta se había declarado «culpable / de las mismas palabras que combato» (2006: 107).
} 
veces conciba la existencia en términos de representación, de «azar de nadas a la nada» (l. c.: 366) (es el mundo de payasos, prestidigitadores y lanzadores de cuchillos retratado por Valente en «Invención sobre un perpetuum mobile»); o que incluso no eluda afrontar su propia crítica en textos como «Criptomemorias», donde el escritor nos descubre la naturaleza ficticia de la subjetividad, mera máscara, simple narración de corte autobiográfico a la que el hombre recurre para dotar de algún sentido a su existencia:

Debiéramos tal vez / reescribir despacio nuestras vidas, / hacer en ellas cambios de latitud y fechas, / borrar de nuestros rostros en el álbum materno / toda noticia de nosotros mismos. // Debiéramos dejar falsos testigos, perfiles maquillados, huellas rotas, irredentas partidas bautismales. // O por toda memoria, una partida abierta, un bastidor vacío, un fondo / irremediablemente blanco para el juego infinito / del proyector de sombras. / Nada. / De ser posible, nada (l. c.: 342-343).

Dadas las circunstancias, queda justificado el hecho de que, años más tarde, en «Memorias» (de Al dios del lugar), Valente anotara como única posibilidad de plasmar una biografía auténtica la basada en lo no vivido: «El solo encuentro en el que nunca / nada podría al fin haber pasado. // La posibilidad de todo. // Y esa oscura carencia / de hechos y de días / borraba, más real, / la ficticia hilazón / de tu biografía» (l. c.: 479). «Nunca escribiré mis memorias. Todas las memorias están falsificadas. Escribiré las de otros, escribiré la autobiografía de otra persona», declararía Valente en entrevista mantenida con Nuria Fernández (2000: 149) ${ }^{18}$.

Por otra parte, este tratamiento de lo subjetivo acusa el influjo de otras reflexiones desarrolladas en los ensayos incluidos en Las palabras de la tribu,

${ }^{18}$ Precisamente al respecto del género autobiográfico, Valente establece en «Una breve memoria» (1987: 11) una posible configuración para el mismo en clave de alteridad: «La autobiografía es siempre autobiografía del otro: del otro o de los otros que fuimos. [...] En la autobiografía, la mediación de la memoria multiplica los rostros en el espejo, no siempre desinteresado o fiel, del yo que en el ahora y en el aquí los interroga. Es la autobiografía, por su naturaleza misma, un género en el que la ambigüedad y las máscaras —el yo y sus ficciones - se entremezclan y abundan. Naufragio radical de la automemoria en la infinitud de los espejos cruzados. Cómo reconstruir ahora el rostro de nuestros días más lejanos. A veces, casi siempre, es algo exterior a nosotros mismos [...] lo único que da al yo rememorante algún indicio fidedigno de sí. Ciertos objetos, ciertos seres han quedado fijados [...] como referencia de aquél, de aquello que en las formas sucesivas de uno mismo se ha ido disolviendo o alejando. Puntos de afección, asideros de la memoria personal, que acaso gracias a ellos, tan sólo, se sostiene. También aquí es el otro, la existencia del otro, lo que sustenta la supervivencia nuestra en la propia». Y si bien es cierto que Valente nunca llegaría a escribir sus memorias, no debemos obviar la existencia de una más que reveladora 'entrevista vital' concedida por el escritor a RodríGUEZ Fer, C., publicada en dos partes («Entrevista vital a José Ángel Valente: de Ourense a Oxford», Moenia, vol. 4, 1998, pp. 451-464; y «Entrevista vital a José Ángel Valente: de Xenebra a Almería», Moenia, vol. 6, 2000, pp. 185-210), y en la que el escritor aborda diversas circunstancias de su existencia. 
como por ejemplo la que nos ayuda a delimitar la estirpe poética de la que parte nuestro escritor a estudio, que no es otra que la de la poesía meditativa (se trata de un detalle importante, teniendo en cuenta que otros, a la hora de plantear el modo de acceso al conocimiento otro de la realidad, optarán por seguir las rutas abiertas por el surrealismo). Lo que veía Valente en esta corriente meditativa, escasamente cultivada por la lírica española de la modernidad, era no sólo una vía de aproximación a la evolución natural de la literatura europea, sino también un modo de estrechar el vínculo entre poesía y filosofía. Valente otorga a Unamuno el papel fundacional en la génesis contemporánea de lo meditativo en España (tradición donde también incluye a Machado, Cernuda y al Juan Ramón del exilio).

Asimismo, es indudable la importancia fundamental que la estancia de Valente en Oxford entre 1954 y 1958 tuvo en su elección de dicha corriente. Fue allí donde, con la excusa de la realización de una tesis doctoral — nunca leída finalmente - sobre la influencia de la literatura española en la literatura inglesa del siglo XVII, traba contacto con la poesía metafísica inglesa, lo que le ayuda a refrendar no pocas intuiciones surgidas de su lectura de Cernuda. Y si bien en 1962, tal como leemos en «Luis Cernuda y la poesía de la meditación», Valente se distanciaba de la modalidad más religiosa de la poética meditativa y, cercano al pensamiento de Coleridge (y por supuesto al de Cernuda), abogaba por entender lo meditativo como un estado espiritual asociado a la imaginación como mecanismo creador, con el tránsito de los sesenta a los setenta, reduciría las distancias entre ambas concepciones para, apoyándose en su profundización en el estudio de las formas literarias de la mística, acabar por establecer una peculiar propuesta basada en lo sagrado como única posibilidad de autenticidad de la experiencia poéti$\mathrm{ca}^{19}$. (Esta reflexión sobre lo meditativo prosigue en «Rudimentos de destrucción», artículo donde se distingue entre religión y ortodoxia por un lado, y conciencia religiosa o de lo sagrado por el otro. Así, tras ponerse de relieve el carácter alienante de las primeras, se adjudica a la segunda una naturaleza «creadora capaz de alojar una epifanía de lo real [...], una revelación de lo divino» -2002a: 70—. Esta caracterización se prolonga al ámbito del lenguaje, donde a la «gestión totalitaria de formas conclusas» propia de la ortodoxia, Valente opondrá el «movimiento creador o liberador de lo que pugna por manifestarse o ser» - $l$. c.: $71-$ característico de la

${ }^{19}$ Recordemos que ya Heidegger, en «¿Y para qué poetas?» (conferencia pronunciada en 1946, incluida en HeidegGer, M., Caminos de bosque, Madrid, Alianza, 1998), había establecido lo siguiente: «Ser poeta en tiempos de penuria significa lo siguiente: cantando, prestar atención al rastro de los dioses huidos. Por eso es por lo que el poeta dice lo sagrado en la época de la noche del mundo» (p. 201). Tampoco deberíamos olvidar al respecto esta otra circunstancia, anotada por Valente en «Sobre la lengua de los pájaros»: «La lengua poética ha sido la lengua originaria de lo sagrado en todas las tradiciones» (2000a: 243). 
conciencia de lo sagrado, y también definido como «movimiento de destrucción y reinvención que es a la vez abolición de la realidad y acceso a formas más profundas de ésta» — ibid.—. No cabe duda de que la meditación sobre lo religioso y lo sagrado se halla en nuestro escritor desde sus inicios, ya sea a través de los ensayos —al respecto, resulta ciertamente esclarecedor un artículo como «Nuevos maestros», en el que Valente, más allá del reconocimiento hacia dichos maestros ${ }^{20}$, muestra su convencimiento en la verdad de la doctrina cristiana entendida desde una radicalidad de la que pronto abominaría - o a través de las obras de creación —en donde el poso, en concreto, del imaginario cristiano, es notable en los ámbitos simbólico, temático, intertextual, etc.- - Lo cual invita a aventurar la presencia en el poeta de una tensión no muy alejada de la descrita por G. Steiner en Nostalgia del absoluto - alimentada, por un lado, de la constatación del vacío existencial, moral e intelectual resultante de la decadencia de los sistemas teológicos en la sociedad occidental, y, por el otro, de la angustiosa necesidad de cubrir dicho vacío- y finalmente en vías de resolución en el tránsito de los sesenta a los setenta, a través de esa pervivencia en la obra de Valente, si no de la creencia original, sí del impulso trascendente - lo sagrado como forma de vinculación entre el hombre y la realidad- en el que se sustentaba aquella.)

Pero analicemos más detenidamente la época en la que nos hallamos. J. Á. Valente nos guía por el clima literario de aquel tiempo:

Percibía yo [...] cómo en el instintivo o espontáneo rebrote de lo religioso que, junto con otros elementos, compuso el cuadro de aquellos años, se buscaban ciertos espacios o formas de experiencia interior en otras tradiciones, sin pensar acaso que habían encontrado también muy alta expresión en la cultura de Occidente, aunque hubieran quedado en ésta sumergidas o marginadas («Breve historia de una edición», 2000a: 258-259).

Valente se refiere a esa corriente del pensamiento occidental, más o menos soterrada, representada por figuras como el Maestro Eckhart, Giordano Bruno, Hildegarda de Bingen, san Juan de la Cruz o Miguel de Molinos, una línea con claras analogías con el pensamiento extremo-oriental (por ejemplo, coinciden en una visión del mundo que privilegia la fusión de contrarios al establecimiento de dualidades irreconciliables). Valente, atendiendo a la mayor cercanía a la realidad que según él representa esta vía, cree llegado el tiempo de su rescate para la contemporaneidad. No es el primero. Él mismo menciona a A. Huxley como verdadero impulsor del retorno contemporáneo a la mística, así como a Machado y al Valle-Inclán de La lámpara maravillosa, dentro del ámbito español. En los años venideros, el estudio pormenorizado de las diversas tradiciones místicas (europea, judía, árabe, extremo-oriental) aportaría

${ }^{20}$ Concretamente, T. Fernández Miranda y A. D’Ors. 
a Valente vías hasta entonces escasamente transitadas en nuestro país desde las que afrontar el compromiso con la realidad y la palabra.

Un artículo fundamental, «La hermenéutica y la cortedad del decir» (1969), nos orienta al respecto. En él se afirma que en la mística, «la palabra se hace conocimiento de lo que consiste en un no conocer, en un no saber, en un más allá de todo conocimiento» (2002a: 66), meditación que trasladada a la esfera de la creación valentiana nos permite establecer una pauta en clave de tránsito de aquella inicial concepción de la poesía como conocimiento a otra que afirmará haber hallado en el inconocimiento esa ansiada vía de acceso a lo oculto de la realidad ${ }^{21}$. El mismo escritor nos lo confirma a través de este fragmento posterior de inconfundible aroma sanjuanista:

La apuesta es irrenunciable: llevar el lenguaje a una situación extrema, lugar o límite donde las palabras se hacen, en efecto, 'ininteligibles y puras', con una teoría del no entender, no saber [...], de forma que el que en un simple modo de razón no entienda pueda encontrar, no entendiendo, más hondo y dilatado espacio para existir («Palabra, libertad, memoria», 1997: 39).

Giro hacia las formas y los contenidos desarrollados por las figuras históricas de la literatura espiritual española, en las que Valente encuentra un paralelismo con su propio empeño en generar un espacio lingüístico propio. Por otra parte, no debemos olvidar la consideración (que el poeta reconoce) la experiencia mística como experiencia de la interioridad, ya se enfoque aquella como descenso radical hacia el centro o bien como movimiento de salida y retorno. Una consideración, además, que combinada con la reflexión sobre la materia desarrollada en «Cinco fragmentos para Antoni Tàpies», se constituye en la clave de bóveda sobre la que, ya camino de los ochenta, Valente armará una nueva consideración de la experiencia y la palabra poéticas, que vendrá asimismo acompañada de una nueva propuesta de definición del concepto de subjetividad. Pero vayamos por partes.

Al respecto del primer aspecto, no estaría de más recordar que la concepción de la palabra valentiana se sostiene en el mito de la palabra del origen, el 'nombre divino único' génesis de todas las cosas, palabra primordial de la que encontramos diversas formulaciones a lo largo y ancho de la obra valentiana: 'antepalabra', 'palabra matriz de todas las significaciones posibles', palabra absoluta «sin significación en ella misma, pero preñada de significación» (definición esta recogida de Scholem -2000a: 63-), 'logos espermático' o 'palabra-semen', etc. No cabe duda de que la restitución a la

${ }^{21}$ Acierta Ellen Engelson Marson en su descripción de este paso en «Una peregrinación por el pensamiento crítico de José Ángel Valente: En busca del centro poético» (RodríGuez Fer, C. (ed.), Material Valente, Madrid, Júcar, 1994), «Ahora, en vez de entenderlo como revelación de lo meramente escondido, como había sugerido en su período anterior, el poeta empieza a buscar lo que todavía no ha llegado a ser y lo que, mejor dicho, "se busca a sí mismo"»(p. 63). 
humanidad de esta palabra sagrada del origen, hoy perdida y olvidada, constituye el más alto destino al que puede aspirar un poeta, al menos desde la orilla estética representada por Valente. Designio irrealizable, por supuesto, pero al que el poeta, si en puridad quiere ser considerado como tal, nunca debe renunciar. En aras de ello se aventura en el lenguaje, al que somete a un proceso de reversión que pueda acercarle a ese logos original ${ }^{22}$.

El más breve poema lírico encierra en potencia toda la cadena de las rememoraciones y converge hacia lo umbilical, hacia el origen. Por eso, en la teología griega de las Musas, éstas [...] cantan comenzando por el origen [...], es decir, proyectando todos los estratos de sentido a un origen donde, según otra revelación, estaba la plenitud de sentido de la palabra, el logos. De ese modo, toda operación poética consiste, a sabiendas o no, en un esfuerzo por perforar el túnel infinito de las rememoraciones para arrastrarlas desde o hacia el origen, para situarlas de algún modo en el lugar de la palabra, en el principio, en arkhé (2002a: 62) ${ }^{23}$.

Movimiento de retracción en el que, por tanto, se van revelando las infinitas capas de la memoria, del «vasto territorio de todo lo que aún no recordamos» («Poesía, filosofía, memoria», 2004: 163); descenso hacia lo hondo

${ }^{22}$ Todos estos planteamientos podrían fácilmente inducirnos a una consideración de la poética valentiana en clave de mera nostalgia de una presunta edad de oro, lo que podría movernos a enjuiciarla como una muestra más de logocentrismo. En «José Ángel Valente: el cuerpo y el lugar de la escritura» (en Material Valente, pp. 134-135), A. Terry nos avisa de lo desacertado de tal valoración. Recordemos que si bien es patente en la obra lírica de Valente esa nostalgia del origen de lo informe, esta nunca deriva en la defensa de una forma 'conclusa', cerrada en su perfección.

${ }^{23}$ Me parece observar, al respecto de la noción de rememoración valentiana, los ecos de dos conceptualizaciones procedentes del ámbito del pensamiento alemán, la Er-innerung ('interiorización rememorante') de Hegel (reformulación de la anamnesis platónica que debemos entender en clave de acopio en el interior del espíritu de aquello que previamente se presenta como externo), y el An-denken ('pensamiento rememorante') de Hölderlin, noción esta última en la que el juego entre exterioridad e interioridad nos remite a un movimiento de retorno a lo originario. Recordemos que Heidegger, basándose en este perfil originario, cifra en el An-denken la vía de superación de la metafísica (caracterizada por el olvido del ser en favor del ente), por cuanto gracias a él, el ser puede ser pensado como lo diferente, lo 'otro del mundo', posibilitando así una apertura ontológica en la que asimismo resulta fundamental el acceso a esa otra figura de la alteridad que es el silencio (de ahí que Heidegger, para quien - tal como especifica en su comentario del poema de Hölderlin «Como cuando en día de fiesta»- una resonancia de la palabra auténtica sólo puede brotar del silencio, nos recuerde lo ineludible del An-denken en todo poetizar que se pretenda esencial). Aun así, volviendo a nuestra argumentación principal, dichas consideraciones, insisto, no deberían ir más allá de su caracterización como ecos, no sólo porque la indiscutible fuente de la que Valente extrae el cuerpo principal de sus teorías es la tradición mística, sino porque lo que fundamentalmente subyace bajo el concepto de rememoración, en la poética valentiana, es una propuesta con entidad propia, que más allá de ubicarse en y frente a una tradición, se constituye en verdadera aproximación hermenéutica a la propia obra y a la manera en que esta afronta el problema de lenguaje que se plantea a todo escritor. 
en el que la palabra nos abre su interioridad, «formada por el infinito depósito de la memoria y de los tiempos» («El cante, la voz», l. c.: 36); de ahí que Valente vea en este abismarse la operación fundamental de la poesía ${ }^{24}$. El escritor, apoyándose en estas y otras reflexiones similares, interpreta su propia evolución poética, que se conformará alrededor de tres descensos, los correspondientes a la memoria personal, la memoria colectiva y la memoria de la materia:

Nos invita el poema a una experiencia oscura, a la inmersión en las capas sucesivas de lo que antes he llamado «palabra materia», en el fondo infinito de las cuales se encuentra la palabra única, la que fue, no sabemos cuándo, nuestro origen. Inmersión, pues, en las capas de la memoria. Ese descenso o viaje es, como todos los viajes, un rito de iniciación que, en mi perspectiva personal, tendría tres fases, o tres grandes ciclos, o tres grandes pruebas: el ciclo del descenso a la memoria personal, el descenso a la memoria colectiva y el descenso a la memoria de la materia, a la memoria del mundo. [...] esas fases no son rigurosamente sucesivas, la palabra poética avanza también simultánea o desigualmente en esos tres grandes frentes de la memoria (2001a: 22-23).

'Palabra materia': la que no comunica ni guarda intención alguna, pues el suyo es un saber de quietud, de ahí que en ella fluyan (o se suspendan) los sentidos de forma imprevisible; palabra que ausculta el enigma sin cancelarlo, que, al mismo tiempo que se manifiesta, nos revela el indecible en que se funda; palabra del límite, pues «nos remite al origen, al arkhé, al limo o materia original, a lo informe donde se incorporan perpetuamente las formas» («Sobre la operación de las palabras sustanciales», 2002a: 63) ${ }^{25}$. De ahí que Valente, en un artículo de principios de los noventa, declare el carácter de perpetuo recomenzamiento de todo poema:

Volvemos una y otra vez a la palabra inicial, a la sola palabra poética, palabra de la germinación, que recita ininterrumpidamente el comienzo o el origen. [...] El sentido naufraga en su noche. Noche del sentido en la que la palabra es un solo aparecer oscuro de materias lumínicas y el poema ese solo aparecer, ese oscuro fulgor («Aparición y desapariciones», 2004: 68) ${ }^{26}$.

${ }^{24}$ En «Edmond Jabès: judaísmo e incertidumbre», encontramos la siguiente definición de poesía: «arte de la memoria» (2004: 89).

${ }_{25} \mathrm{~J}$. Ancet establece una interesante identificación entre la consideración valentiana de la materia y las de materia-energía de la física contemporánea o materia-pneuma de la alquimia (1989: 26).

${ }^{26}$ Sin duda, una de las más brillantes expresiones en la poesía de Valente de ese perpetuo engendramiento la tenemos en los poemas en prosa que integran Tres lecciones de tinieblas (1980), y concretamente en la elección de un recurso (sólo en apariencia) tan simple como el del signo gráfico de los dos puntos como nexo de unión de las proposiciones que integran las composiciones. Para A. Sánchez Robayna, Tres lecciones de tinieblas constituye la «expresión radical del proceso de tensiones y formaciones en que la palabra toma cuerpo» en la poesía valentiana; «palabra que nos muestra, en su brotar oscuro, el proceso mismo que la ha llevado a ser palabra» (2006: 43). 
En 1983, se publica La piedra y el centro, una recopilación de ensayos de horizonte esencialmente místico, a medio camino entre el estudio erudito y la teoría literaria. A través de algunos de los artículos incluidos en el volumen, Valente nos abre las vías para un nuevo entendimiento de lo subjetivo, centrado ahora en una formulación de la intimidad que, una vez consumado el movimiento de apertura al otro y retorno al sí mismo, quedaría finalmente conformada en términos de coincidentia oppositorum (es «en la sustancia última del alma [...] donde [...] se opera la unificación de contrarios: humano-divino, esposa-amado, exterior-interior, cuerpo-alma, femenino-masculino»——Eros y fruición divina», 2000a: 45-). Es indudable la profunda deuda que esta concepción de la subjetividad guarda con la experiencia mística (así como el carácter análogo de la misma con respecto a la que, bajo el marbete de subjetividad mística, describe Amador Vega en «Nihilismo de Oriente, nihilismo de Occidente») ${ }^{27}$. Asimismo, con este planteamiento, a la crítica de todos aquellos rasgos definitorios de la modernidad establecidos al inicio de nuestra argumentación, a la falta de confianza en la razón y el método científico, en el yo absoluto, en los discursos ideológicos, se viene ahora a añadir, en virtud de este nuevo horizonte de percepción unitaria de la realidad, una nueva recusación: la del dualismo como método de configuración y de jerarquización del pensamiento, lo que en la práctica supone la abolición de las dualidades materia-espíritu, cuerpo-alma, interior-exterior o sujeto-objeto $^{28}$.

Dos de los ensayos incluidos en La piedra y el centro nos aportan dos

${ }^{27}$ En este artículo, incluido en Zen, mística y abstracción (Madrid, Trotta, 2002), Vega, que presenta notables coincidencias con Valente en las fuentes consultadas, aboga por el establecimiento de un nuevo patrón subjetivo de signo místico. Según el ensayista (que tiene como horizonte la enunciación de una propuesta que nos aproxime a una comprensión verdadera de la realidad), una vez constatadas la ausencia de Dios y la estrechez de los enfoques de signo cartesiano, la reconstrucción de la relación entre el yo cognoscente y el mundo sólo puede ser afrontada desde una concepción 'mística' de la realidad en la que tanto inmanencia como trascendencia consigan encontrar acomodo, y en la que la subjetividad se plantee en términos de experiencia de la unidad basada en la apertura al otro, un proceso que no sólo impida que el yo se sienta tentado de situarse objetivamente frente al mundo, sino que en tanto que posibilita el reconocimiento de la propia nada original, acerque al sujeto su verdadera naturaleza descondicionada y libre (no en vano, para la subjetividad mística la negación es afirmación y la muerte, consecuentemente, vida).

${ }^{28} \mathrm{Al}$ respecto, creo necesario traer a colación el concepto de "unidad simple", acuñado (tal como el mismo Valente nos recuerda en "Sobre el lenguaje de los místicos: convergencia y transmisión») por el Maestro Eckhart. Uno de los aspectos fundamentales de esta unión consiste en la abolición que en ella se opera de otra dualidad esencial: la del yo y el tú. Pues un rasgo característico de la unidad simple es que no sólo el alma sale de sí en busca de Dios, sino que, a la recíproca, también Dios sale de sí en busca del alma. Y es bajo estas circunstancias cuando «la iluminación se funda y con ella la entera transformación de la interioridad» (2000a: 169). Valente ejemplifica esta situación con los conocidos versos de Hallâj: «Yo, que he visto a mi Señor con el ojo del corazón, le digo: ¿Quién eres Tú? Y Él me responde: ¡Tú!» (l. c.: 168-169). 
perspectivas complementarias en la comprensión de esta intimidad nacida del movimiento extático. En el primero, «Pasmo de Narciso», Valente disiente de la interpretación psicoanalítica del mito como funesto regressus ad uterum, y nos propone una relectura del mito en clave de «epifanía del otro en la imagen de sí» (2000a: 22). Para el poeta, el espejo ahora se conforma como «el elemento sacro que permite el deslizamiento o separación del uno hacia el otro de sí, sin que la unidad se rompa, pues la separación en la imagen sigue siendo unidad en la visión» $(l . c .:$ 22-23). Valente nos recuerda que Narciso «antes de ver en la fuente, no veía» (l. c.: 23) y que el hecho de que dicha visión prosiga en la Estigia nos da la clave de un mito «de amor, de supervivencia o de resurrección»(ibid.). Gracias a la imagen, el uno genera al otro de sí y tiene acceso a una visión íntima de sí mismo y de la realidad hasta ese momento insospechada: «En la mediación del espejo o de las aguas, el sí mismo se descubre como otro y ambos quedan amorosamente unificados — pasmo de Narciso- en la visión» (ibid.). (No cabe duda de que nos encontramos lejos de aquellos primeros desarrollos del motivo de la incapacidad del yo para reconocerse frente al espejo, consignados al analizar el recurso de la ironía en la obra valentiana. Así, lo que en la década del sesenta fue visto desde la angustia y una actitud de probada negatividad, ahora es considerado desde la afirmación que supone su enfoque como operación del (in)conocimiento.)

Una perspectiva no muy alejada (si bien enmarcada en el más habitual tópico amada-amado) protagoniza el segundo artículo, «El ojo de agua», comentario del poema $\mathrm{XI}^{29}$ del Cántico de san Juan de la Cruz. Aquí, Valente, observa como la petición de la amada se orienta no tanto hacia una imagen como al «alumbramiento de un mirar»: «del mirar del otro: del otro de sí, del infinitamente otro que la constituye. No pide ver, pide ser vista. Porque la plenitud del ser es ser plenamente en la mirada del Amado. [...] Y el Amado, al verla a ella, que no es más [...] que ojos del Amado, se ve a sí mismo. Amado y Amada ven y se ven en una sola mirada (l. c.: 80-81)».

Años más tarde, en 1991, se publica Variaciones sobre el pájaro y la red, colección que podemos entender como continuación de La piedra y el centro (de hecho, hoy en día son editadas en un único volumen), y en la que, concretamente en las páginas finales de «Los ojos deseados», encontramos una reformulación de la tesis desarrollada en «El ojo de agua». El escritor vuelve a reflexionar sobre los vínculos entre interioridad y otredad a través de san Juan de la Cruz, si bien esta vez, desde una relectura realizada bajo el prisma de la lacaniana formulación del deseo como 'deseo del deseo del otro'. Sólo este deseo, «deseo de ser deseado o reconocido», «deseo de querer ser», nos hace, en opinión de Valente, «propiamente huma-

${ }^{29}{ } i \mathrm{Oh}$ cristalina fuente, / si en esos tus semblantes plateados / formases de repente / los ojos deseados / que tengo en mis entrañas dibujados!». 
nos» (l. c.: 200). Un deseo que, tal como se refleja en otro ensayo perteneciente a Variaciones..., «Verbum absconditum», nace de una maniobra de despojamiento de uno mismo: «El deseo es esa posibilidad de desdoblamiento que [...] engendra del sí mismo al otro, a ese otro especular cuyo deseo deseamos y en cuyos ojos - los ojos deseados - deseamos que su deseo [...] nos haga existir» (l. c.: 202-203). El yo debe salir de sí mismo y, ayudado por el amor, acceder a la unión con el otro, pues sólo en esta unión podrá 'dar vuelo' a esta palabra que reside en su vacío y acceder así a los estratos más íntimos del ser.

Estamos, por tanto, ante una nueva vuelta de tuerca de esa 'radical heterogeneidad del ser' antes mencionada, entrevista ahora desde una perspectiva de naturaleza dialógica, en la que el acceso a la realidad estaría basado en el amor y la diferencia como fuerzas motoras, haciendo así del enigma del otro el de nuestro yo y viceversa. Fórmula de la intimidad en la que el éxtasis, el movimiento de salida hacia el otro, en virtud del deseo que lo alimenta, nos revela nuestra verdadera naturaleza, que es decir la de la realidad, posibilitando así nuestro acceso a la comprensión de la radical unidad existente entre todas las cosas.

El desarrollo anterior protagoniza un gran número de poemas de J. Á. Valente, como los incluidos en la primera sección de Mandorla $(1982)^{30}$. Así, podemos poner como ejemplo los fragmentos siguientes de «Iluminación» («quedo / encendido de ti como respuesta / engendrada de ti desde mi centro» -2006: 410—); «El temblor» («Busco ahora despacio con mi lengua / la demorada huella de tu lengua / hundida en mi saliva. // Bebo, te bebo» - l. c.: 415-); «Borde» («Tu cuerpo baja / lento hacia mi deseo. / Ven. / No llegues. / Borde / donde dos movimientos / engendran la veloz quietud del centro» —l. c.: 411-); y especialmente, el poema que cierra la sección, «Graal» («Respiración oculta de la vulva. // En su latir latía el pez el légamo / y yo latía en ti. / Me respiraste / en tu vacío lleno / y yo latía en ti y en ti latían / la vulva, el verbo, el vértigo y el centro»-l. c.: 417-).

Sirva como cierre a esta cuestión uno de los últimos tratamientos que

\footnotetext{
${ }^{30}$ No está de más recordar la pluralidad de sentidos que convoca la mandorla en esta poética: símbolo del sexo femenino y, por tanto, figura primordial de la creación, se presenta asociada a «lo cóncavo, lo hueco, lo vacío, la nada» (de ahí que para Terry sea, entre otras cosas, «condición de la nada que tiene toda posibilidad» — «José Ángel Valente: el cuerpo y el lugar de la escritura», Material Valente, p. 138-). Asimismo, en la mandorla se da la coincidencia entre lo erótico y lo sagrado, el acoplamiento entre lo visible y lo invisible, y la posibilidad de acceso a la iluminación. De ahí que Valente la definiera en los siguientes términos: «Espacio, pues, inocupado, tal vez insondable, que nos reclama hacia un interior no finito de sí. El arte de la modernidad, en todas sus manifestaciones, ha sentido el vértigo de esa infinitud» («La experiencia abisal», 2004: 197). A todo ello, además, cabe añadir, la circunstancia del diálogo que, teniendo este motivo como base, se establecería entre las obras de Valente y Celan, quien, recordemos ya concibió una almendra (Mandel, mandorla) habitada por la nada.
} 
recibiera en la obra de Valente, el que se desprende del artículo «Vallejo o la proximidad», en donde la reflexión de esta subjetividad que hemos dado en denominar mística se une a aquella otra del yo entre otros, a la crítica a la ideología y a la defensa del estatuto del sujeto en la sociedad contemporánea planteada en los términos referidos en la nota 13 del presente trabajo. Valente comienza estableciendo el que, según él, constituye el horizonte fundamental de la creación vallejiana, que no es otro que «el sentimiento o la noción misma de la proximidad, de lo próximo o de lo prójimo» (2004: 27). A partir de aquí analiza la relación que en ella se da entre el yo y el tú, y en la que observa una vía de trascendencia del yo a través de la continua intercalación o revelación del tú (por ejemplo, esta sería para nuestro escritor la clave de lectura de un poema como «Masa»). Si bien Valente (que busca llevar su reflexión hacia el territorio de la reivindicación de lo singular de cada uno) matiza lo siguiente: «Ese hombre, el semejante, el otro, el próximo o el prójimo, irrumpe en la poesía de Vallejo en su singularidad, en su particularidad, haciendo reventar, con la súbita, lacerante aparición de lo infinitamente pequeño [...] el vientre hidrópico de las ideologías y el edificio aplastante de la macrohistoria» (l. c.: 28). Valente nos ubica así en «la irreductible particularidad de lo humano» (ibid.) de los seres anónimos como Pedro Rojas, finalmente rescatados gracias a la poesía - no lo olvidemos, arte de la memoria- del olvido al que la gran narración de la Historia los habría condenado sin remisión, y pone punto final al artículo con una encendida apuesta por el compromiso con la vida: «Frente a la macrohistoria, pues, la microvida y, desde ésta, la denuncia de la falsedad de todos los lenguajes en la explosión de dolor o de abandono del prójimo o del próximo o del otro o del hombre en su aparición inmediata» (l. c.: 29).

Uno de los grandes protagonistas de la poética valentiana, en el que se vienen a reunir tanto los perfiles de la alteridad como los de la conciliación de contrarios, es el cuerpo. No en vano, la concepción unitaria de la subjetividad no sólo comporta la abolición de la dualidad interior-exterior, sino también la de cuerpo y espíritu, eros y agape, aspectos ambos que Valente, al igual que la tradición mística, no concibe separados, pues según él, no puede haber experiencia espiritual alguna «sin la complicidad de lo corpóreo. En la plenitud del estado unitivo, cuerpo y espíritu han abolido toda relación dual para sumirse en la unidad simple» («Teresa de Ávila o la figura corpórea del espíritu», V., 2000a: 34) ${ }^{31}$.

31 Una tendencia conciliadora de espíritu y materia que no rechaza la expresión de lo sagrado a través del concurso de lo erótico como correlato o manifestación del mismo. Así, en el ya aludido «Los ojos deseados», encontramos la mención a Gregorio de Nisa, quien «habla de la unión del alma y del cuerpo en la contemplación de la naturaleza divina y explica cómo arde eróticamente el alma abrasada por la llama del espíritu» (2000a: 190). Dentro de esta misma línea justificativa, Valente centra su atención en la Cábala, y 
El fulgor (1984) es el poemario del cuerpo. Y, por supuesto, el del espíritu, siempre que entendamos este como aventura de lo corpóreo ${ }^{32}$. En $\mathrm{El}$ fulgor, Valente reivindica el cuerpo frente a las diversas reflexiones filosóficas y religiosas que lo han mantenido subyugado bajo el dominio de agape, si bien evita toda tentación en forma de radiante exaltación de la voluptuosidad de la carne, más interesado en meditar sobre el enigma que anima a esta. Un cuerpo del que el poeta afirma su entera latitud, y en el que se opera la coincidentia oppositorum, congregándose así en él sueño y despertar, claridad y oscuridad, cosmos y microcosmos, así como toda destrucción («En algún pliegue / de ti / estaba, cuerpo, la muerte ritual»—《XVI», 2006: $449-$-) y todo renacimiento («Cuerpo, lo oculto, / el encubierto, fondo / de la germinación»—《XV», ibid.-). Cuerpo ausente o extinto («ciego fantasma / de su nunca mañana» — «VII», l. c.: 446-, «cuerpo todo / quebrantado»-《XIV», l. c.: 448-), la experiencia del cuerpo nos habla también de su dolor y su melancolía, pero, al igual que en el mito de Lázaro, con un reverso en clave de despertar, de memoria de la luz, de iluminación.

De tal manera que podemos afirmar que en este poemario, el cuerpo nos convoca al enigma de su alteridad. Y, correlato de la palabra, lo hace de forma análoga a esta, agazapado tras un fulgor instantáneo que, al tiempo que resplandece, se consume y nos devuelve finalmente a lo impenetrable, dejándonos el destello, la vibración de lo irreductible, de lo sagrado. Así, en «VIII» el poeta sigue al cuerpo en su descenso hacia el centro, la oscuridad, la materia del amor, en una prueba de la interioridad que nos acabará revelando la nocturnidad de la corporalidad, su nada esencial. De hecho, en la experiencia del cuerpo, al igual que sucede con la de la palabra, la frontera entre interioridad y exterioridad queda abolida; de ahí que sea en el territorio de lo corporal no sólo donde se engendra la palabra que se funda en lo indecible («Con las manos se forman las palabras, / con las manos y en su concavidad / se forman corporales las palabras / que no podíamos decir» — «XXVI», l. c.: 453-), sino también el poeta: «Asciendes como / poderoso animal / por la pendiente húmeda / del aire donde / me engendras, cuerpo, en tu latido cóncavo» («XXI», l. c.: 452).

Pero además (y abrimos ahora un nuevo y fundamental frente en nuestro planteamiento), del cruce de las reflexiones sobre la palabra y la subjetividad nace una de las más lúcidas y audaces teorías sobre la creación

afirma que para esta «tanto la relación conyugal como el hecho sexual son medios por excelencia de conocer a Dios y de unirse a él» $(l . c .:$ 192). Este otro apunte cercano aporta un enfoque complementario al análisis de lo erótico en la propia creación valentiana: «Los cabalistas recurren para la expresión de los más velados secretos al lenguaje del cuerpo, y en particular al de la sexualidad que, cuando encuentra debida realización en el acoplamiento humano, se llama "conocimiento"» (l. c.: 194).

32 «El vuelo del cuerpo y del espíritu son una misma cosa» (2002: 32), escribirá el poeta en «Elogio del calígrafo». 
poética y el estatuto del escritor contemporáneo de los últimos tiempos, próxima a la formulación del sujeto místico, y según la cual el poeta, en su movimiento de apertura al otro, de descenso por los pliegues de la memoria, de solícita entrega a la germinación de esa palabra que brota del silencio, alcanza, finalmente ajeno a intencionalidad alguna, un estado de vacío, de espera y de disponibilidad infinita, en el que a la postre se hace posible la revelación del residuo último de tal experiencia: el poema.

De acuerdo a esta teoría, Valente establece la misión fundamental del poeta: crear la nada, posibilitar el vacío en el que sea posible la encarnación de la palabra. Sin duda el pasaje definitorio por antonomasia de esta concepción de lo poético es el delimitado por las líneas iniciales de «Cinco fragmentos para Antoni Tàpies», en Material memoria (1979):

Quizá el supremo, el solo ejercicio radical del arte sea un ejercicio de retracción. [...] Crear lleva el signo de la feminidad. No es acto de penetración en la materia, sino pasión de ser penetrado por ella. Crear es generar un estado de disponibilidad, en el que la primera cosa creada es el vacío, un espacio vacío. Pues lo único que el artista acaso crea es el espacio de la creación. Y en el espacio de la creación no hay nada (para que algo pueda ser en él creado). La creación de la nada es el principio absoluto de toda creación (2006: 387) ${ }^{33}$.

Complementario del texto anterior, tenemos este otro fragmento de M. Tobey («Que la naturaleza domine en tu obra. Estas palabras de mi viejo amigo Takizaki, vagas al principio, se aclaran con la idea: Bórrate» -2002: 50—), recogido por Valente, y al que, después de reconocer la facilidad con que semejante consejo suele caer en el olvido, añadirá: «Sin ese autoborrarse, que crea en primer término el vacío o la nada, ninguna creación es posible. Determinante antecomienzo» ( $l$. c.: 51$)$; lo que nos remite a uno de los poemas más representativos de nuestro autor, «Borrarse», de Al dios del lugar: «Borrarse. I Sólo en la ausencia de todo signo / se posa el dios» (2006: 464).

En el fondo, lo que está en juego en esta situación de desposesión es la naturaleza anónima de toda obra, consecuencia directa de la convergencia del autor con el principio iniciador o movimiento primario, el Ursatz, tal como queda manifiesto en este otro fragmento:

En el punto de unificación de la forma, la referencia al hombre o al autor — ¿quién es el autor? - está ya de antemano disuelta. La experiencia personal ingresa en el movimiento natural del universo, en el Ursatz, en el movimiento

${ }^{33}$ En la misma línea, Valente solía citar a Isaac de Lulia como apoyo a su argumentación: «La creación exige del creador una participación por retirada hacia el interior de sí mismo, para dejar un espacio por él no ocupado, donde la aparición del otro o de lo otro sea posible. Exilio de Dios hacia el interior de Dios, como pensó Isaac de Luria [...], para que en ese espacio por él abandonado, pero húmedo de sus residuos germinales, fuese posible el universo. Lo primero - o lo único- que el creador crea es la nada, el espacio de la creación» («Sobre la unidad de la palabra escindida», 2004: 51). 
primario que, a la vez, la precede y la sucede. La obra es así anónima, como la poesía está, en verdad, hecha por todos («Las condiciones del pájaro solitario», 2000a: 20-21).

Esta y otras reflexiones se dan cita en la tercera sección de Mandorla, planteada como una genuina poética valentiana (en ella encontramos referencias al vacío previo a toda creación; a la actitud de espera a la manifestación de la palabra; y fragmentos tan característicos de nuestro escritor como los siguientes: «Escribir es como la segregación de las resinas; no es acto, sino lenta formación natural. [...] Escribir no es hacer, sino aposentarse, estar» (2006: 423); «Palabra de tal naturaleza que, más que alojar el sentido, aloja la totalidad del despertar" (l. $c .:$ 424); «Momentos privilegiados en los que sobre la escritura desciende en verdad la palabra y se hace cuerpo, materia de la encarnación» (ibid.); o textos como «Il tuffatore», conciso poema en prosa en el que no parece posible deslindar la reflexión literaria de la ontológica: «No estamos en la superficie más que para hacer una inspiración profunda que nos permita regresar al fondo. Nostalgia de las branquias» (ibid.).

Pero ¿cómo se desarrolló este proceso en el tiempo? ¿Cuál es su genealogía? Para ubicar los primeros momentos del mismo, debemos volver atrás, concretamente a ese trascendental tránsito de los sesenta a los setenta, en que Valente traslada su desconfianza del yo al ámbito de la autoría. Un artículo capital, «La poesía. Conexiones y recuperación», escrito en 1970, nos ilumina al respecto: el escritor parte de la formulación de Keats del poeta como camelion Poet o poeta camaleón: «el camelion Poet carece de yo, es todo y es nada, y no tiene contenido, ni luminoso ni sombrío, que le sea propio» (1970: 42). Así, el poeta, pura indeterminación, no posee identidad propia, siendo ese su estado ideal, pues sólo en tal circunstancia «puede dar paso en él a la libre circulación del universo, a lo que espera encontrar su identidad en un medio (el propiamente creador), donde otra identidad no condicione o aborte su manifestación» (ibid.) ${ }^{34}$. Valente nos recuerda que «Toda palabra condicionada o predeterminada por una espuria pretensión del poeta a la identidad nace muerta» $(\text { ibid. })^{35}$.

${ }^{34}$ Una configuración del poeta cercana a esa otra del poeta como hombre-árbol recreada por María Zambrano en Pensamiento y poesía en la vida española (1939): «con los brazos abiertos ante la creación el poeta se abre a todas las cosas, se ofrece íntegramente sin ofrecer resistencia a nada, quedándose vacío y quieto para que todas las criaturas aniden en él; se convierte en simple lugar vacío donde lo que necesita asentarse y vaga sin lugar, encuentre el suyo y se pose» (en ZAMBRANO, M., Obras reunidas, vol. 1, Madrid, Aguilar, 1971, pp. 293-294).

${ }^{35}$ En este breve artículo hallamos asimismo el siguiente fragmento, en el que reconocemos algunos de los temas desarrollados en el presente ensayo: «La no identidad del poeta tiene su reflejo en la disponibilidad de la palabra no determinada por contenidos previstos, capaz así de posibilitar la libre (no censurada) circulación del universo, el estallido de la 
La reflexión anterior, por supuesto, encontró pronto reflejo en la práctica poética. Así, en «Retrato del autor», de El inocente (1970), el poeta, como paso previo a su disolución, es escarnecido y despojado de toda la pompa y boato que suele rodear su oficio. Así, el yo explica burlonamente su circunstancia literaria y existencial ( $\ll$ Je suis un poète / J'ai quarante ans / et je suis content» -2006: 293-) a su propio perro, antes de hacernos copartícipes de la mofa a través de la conocida apelación baudelairiana al lector.

Hacia finales de los ochenta, Valente, seguramente por esa influencia à rebours («influencia hacia atrás, hacia la fuente o el origen» - 2004: $90-$ ) derivada de la lectura de la obra de E. Jabès (y por otra parte complementaria de otra circunstancia fundamental que trataremos en breve, el creciente peso que el tratamiento de la figura de la nada iría adquiriendo en la obra valentiana), comienza a dar prioridad al aspecto del exilio sobre el del éxtasis. Así, el desierto, el exilio, el 'no lugar', se perfila como el espacio de apertura de la palabra poética, porque sólo en ese «absoluto territorio del ser errante» («La memoria del fuego», 2000a: 255) puede generarse «un estado de desnudez o transparencia, en el que las palabras [...] "se pronuncian a sí mismas"» (l. c.: 256). «Estado de escritura. Estado de espera o de escucha, no del que va a decir o a utilizar la palabra [...], sino del que va a comparecer ante ella» $(l$. c.: 253), pues no es el poeta el que dice la palabra, sino esta la que elige y "dice” al poeta. De ahí que, tal como se afirma en «Como se pinta un dragón», «El poema no se escribe, se alumbra» (1997: 21).

Establecidas las anteriores premisas, convendría evitar el error de pensar que con su propuesta Valente, en realidad, esté abogando por una idea de la creación cercana al automatismo inconsciente del surrealismo, o de identificarla con el concepto de inspiración como rapto divino descrito por Platón en sus diálogos. De hecho, para Valente, la figura del poeta verdadero estaría tan alejada de la del poeta dueño de todas las claves como de la de aquel otro poseído o alienado. Nuestro escritor se vale de tres correlatos fundamentales a la hora de perfilar el poeta verdadero: el cantaor, el arquero y el místico. En todos ellos, el paralelismo con el poeta queda establecido en torno al hecho de que sus experiencias se traducen en un desbordamiento de las respectivas conciencias, que posibilita el acceso a una iluminación más allá de los límites habituales, y en la que cantaor, místico o arquero (al igual que sucede con el poeta y su escritura) resultan finalmente indistinguibles de su arte.

La figura del cantaor está presente en dos artículos, «La piedra y el centro»y el ya citado «El cante, la voz», singulares en su caracterización

realidad bajo las formas rígidas que lo ya previsto le impone, la reabsorción del lenguaje en un punto cero en que el signo vuelve a hacerse pura expectativa de la significación o lugar donde es posible (gracias a la destrucción creadora de los contenidos que inmovilizan al lenguaje mismo) la manifestación de lo que ha estado oculto» (1970: 42). 
del cante (es decir, de lo poético) como forma de la interioridad de la palabra en la que el cantaor (o lo que es lo mismo, el poeta) se va haciendo palabra ( «La palabra en el cante nos lleva hacia su oscuridad. La oscuridad es su luz. Cuando un cantaor alcanza ese límite extremo, cuando en su cante llega al punto en que la oscuridad y la luz se unifican, ha entrado en el territorio primordial de lo poético, territorio donde el hombre es el poseído de la palabra» -2004: 37-).

En cuanto al arquero, tenemos que una vez logra prescindir de su voluntad, es decir, cuando (al igual que el poeta) se libera de toda intencionalidad, sólo entonces logra mantenerse (con el arco cargado en posición de tiro) en un estado de espera, de máxima tensión y completa receptividad cósmica, en el que (una vez el blanco y él son ya una misma realidad en el universo) la flecha, finalmente, ante la sorpresa del propio sujeto, se desprende del arco y alcanza su destino ${ }^{36}$.

Al respecto del místico y su experiencia unitiva, recordemos que esta sólo puede acontecer una vez el sujeto se halla en un estado de transparencia total como consecuencia de un proceso de vaciado del yo, activado mediante una maniobra previa de salida del yo de sí mismo o éxtasis, y que Valente define (en palabras que ya deberían sernos familiares) como «proceso de descondicionamiento del alma en el que ésta va reduciéndose a su solo centro, que ha de vaciarse de toda forma o imagen creada para que en el alma, ya de sí salida, se llene ese centro vacío con la plenitud de lo que no tiene forma ni imagen y encierra a la vez la potencialidad infinita de todas las formas de la creación» («Ensayo sobre Miguel de Molinos», 2000a: 91) ${ }^{37}$.

Este fragmento, perteneciente a una entrevista concedida por el poeta, no sólo viene a resumir esta cuestión del estatuto del autor, sino que sirve de introducción al último tema que vamos a abordar, el papel de la nada en la obra de J. Á. Valente:

El creador tiene que ir acostumbrándose a la aniquilación del «yo» que es el proceso de purificación espiritual. Toda creación literaria auténtica, poética [...]

${ }^{36}$ La imagen del arquero proviene, como es bien sabido, de El zen en el arte del tiro con arco, de E. Herrigel, y del que Valente afirma lo siguiente: «Manual, como los de todas las artes regidas por el zen, del perfeccionamiento o de la progresión interior que contiene, a la vez, una luminosa apertura a la creación [...], es decir, una estética» («Rumor de límites», 2002: 36). La lectura de este libro supuso para Valente una experiencia «fulminante» (ibid.), que asimismo quedaría reflejada en el poema XXXVI de Treinta y siete fragmentos.

${ }_{37} \mathrm{Al}$ respecto, me parece oportuno traer a colación la interesante reflexión que A. Tàpies hace al respecto del éxtasis en «Conversación entre Antoni Tàpies y José Ángel Valente»: «Se cree que ese estado, que también se puede calificar con una palabra que está muy denostada, el éxtasis, es quedarse colgado como de una nube para siempre. Cuando la verdad es que se trata de un estado transitorio. Pero entonces vuelves a la realidad y la comprendes mejor. Y te hace ver más claramente la unidad universal de todas las cosas» (2002: 94). 
tiene que ir acompañada de una experiencia espiritual, si no, no vale nada. Eso lleva a una aniquilación del «yo» y probablemente a una visión de la nada, aunque positiva. Quizá nuestro cometido sea la fusión con el cosmos en el seno de la nada, volver a la nada de donde hemos venido (2000: 147).

Valente nunca abandonaría esta forma de entender la subjetividad a partir de la mística, si bien, con los años, la fue tiñendo con tonos cada vez más sombríos, como si de alguna manera hubiera acabado privilegiando en su creación el influjo de Miguel de Molinos al de san Juan de la Cruz, los perfiles de lo que podríamos denominar íntima o interior aniquilación a los ya vistos de lo que a su vez podríamos nombrar intimidad o interioridad extática ${ }^{38}$.

Se trata de una cuestión de matiz, de tono, pues ambas formas de intimidad coexisten en continuo vaivén a lo largo de toda esta etapa final de la creación valentiana; si bien, no parece descabellado afirmar que mientras la intimidad extática protagoniza Mandorla y El fulgor, la íntima aniquilación marca el tempo de los posteriores Al dios del lugar (1989), No amanece el cantor (1991), así como del póstumo Fragmentos de un libro futuro (2000) ${ }^{39}$.

Determinar un posible discurso para esto que hemos dado en denominar interior aniquilación supone abordar previamente el estudio de uno de los conceptos fundamentales en la poética de J. Á. Valente: la nada. Tarea escurridiza donde las haya, si atendemos al hecho de que, si el fluir del sentido siempre fue algo buscado y privilegiado por nuestro autor, de acuerdo a su forma de entender la creación, ello se cumple en modo extremo al respecto de la figura de la nada ${ }^{40}$, en la que me parece entrever, bajo un mismo significante, al menos, tres modalidades de significación.

La primera de ellas se movería en el ámbito de la creación y, en definitiva, haría referencia al vacío que el poeta debe fundar como paso previo a la aparición de la palabra, y que ya hemos tenido ocasión de examinar.

Las otras dos realizaciones de la nada, en cambio, vendrían a corroborar

38 «Los elementos sobre los que Molinos cimienta la Guía espiritual son el primado de la contemplación y la cesación de los medios, que llevan de por su naturaleza a la doctrina de la nada. [...] Estamos, pues, ante un místico de clara fijación sanjuanista» (2004: 178), afirma Valente en «La nada» (La experiencia abisal). Por tanto, son todos elementos, de acuerdo a nuestro escritor, compartidos por ambos místicos, si bien el mismo Valente ya había observado en «Ensayo sobre Miguel de Molinos» la radicalización que la doctrina de la nada alcanza en la obra del místico aragonés.

${ }^{39}$ Repito que todo esto debe acogerse desde una perspectiva abierta, pues la coexistencia de los dos desarrollos es real, y de hecho el vaciado es un paso inexcusable en ambos. Valga como ejemplo de la convivencia de ambos planteamientos el siguiente texto extraído de Fragmentos de un libro futuro: «Salí tras ti. / Devuélveme a tus ojos / que llevo en mis entrañas dibujados» (2006: 571). El poema, de manera harto reveladora, se titula «La nada».

40 Al respecto de esta dificultad para acercarnos a una posible definición de la nada, asimismo conviene no olvidar que, en puridad, de la lectura de los textos valentianos, se extrae el carácter sinónimo que guardan para el escritor los conceptos de nada y vacío, tal como hemos tenido ocasión de comprobar en «Cinco fragmentos para Antoni Tàpies». 
la presencia de esa pulsión de muerte que atraviesa de principio a fin la totalidad de la obra lírica de Valente —incidiendo especialmente ahora en las figuras de la ausencia y la 'descorporeización'—, si bien cada una adoptando diferentes puntos de vista.

Así, en lo que constituiría una segunda acepción de la nada, encontramos esta caracterizada bajo un doble perfil de muerte y renacimiento, que nos hace identificarla con el tema del hombre, de su conciencia de la temporalidad y su anhelo de trascendencia, si bien en una forma completamente alejada de la habitual en nuestra tradición. Esta nada es la que en «La experiencia abisal» es descrita, de acuerdo a K. Nishitani, como «nada positiva, que correspondería a la noción de saanyata, vacuidad o vacío o nada absoluta» (2004: 203). Nada de índole creadora (hasta el punto de que esa primera enunciación de la nada como creación del vacío puede ser considerada el correlato literario y artístico de esta otra definición), se trata de la misma nada a la que M. Zambrano considerara como última manifestación de lo sagrado, nada que «nos acoge como una madre que nos hará nacer de nuevo» ${ }^{41}$. Dos imágenes extraídas de «Sobre la declinación de la luz», la flor y el fuego, resumen la visión de esta 'Gran Nada Primordial' «que antecede a todos los seres individuales del universo y de la que éstos fluyen en sus diversas formas» (2004: 203):

La flor es una luz plena, pero una luz que en su cenit suscita ya la expectativa de una plenitud distinta; la de su apagamiento. La nada. Es la luz, pero ya empieza a ser luz que se apaga (2002: 151).

El fuego. Ininterrumpida aparición y desaparición de la belleza, que desde su propia muerte se sucede a sí misma. En la luz que se apaga arde la semilla de un nuevo nacimiento (2002: 152) ${ }^{42}$.

Ambas imágenes permiten asimismo una lectura en clave de poetización de la hegeliana identificación entre ser y nada, también recogida en «Espacio» (Fragmentos...): «Y todas las cosas para llegar a ser se miran / en el vacío espejo de su nada» (2006: 570). En la misma línea cabría ubicar también el siguiente fragmento de «Así en la tierra como en el cielo»:

\footnotetext{
${ }^{41}$ Zambrano, M., El hombre y lo divino, Madrid, F.C.E., 2005, p. 152.

${ }^{42}$ Esta heraclitiana visión del fuego en clave de perpetua resurrección es la que informa «Fénix», de Al dios del lugar («Quedar / en lo que queda / después del fuego, / residuo, sola / raíz de lo cantable»), adaptación de dicha reflexión a la naturaleza de la palabra. C. Rodríguez Fer, en su introducción a la edición de Cuaderno de versiones, encuentra el sentido de esta composición de carácter metapoético en «La memoria del fuego», donde se afirma lo siguiente: «Palabra que renace de sus propias cenizas para volver a arder. Incesante memoria, residuo o resto cantable: "Singbarer Rest", en expresión de P. Celan. Pues, en definitiva, todo libro debe arder, quedar quemado, dejar sólo un residuo de fuego» (2000a: 257). Palabra abierta, por tanto, a su propia extinción, «para que en la forma que acaso hemos alcanzado sólo se perpetúe la formación» («Del don de ligereza», 2004: 46).
} 
la tierra, el seno del que brotan las semillas, el hondo seno oscuro donde un día seré reasumido, nostalgia cierta de la sombra húmeda donde seré, por fin, reengendrado para ya no morir. La tierra, el humus, el barro original que anuncia al hombre (2002: 61).

Pulsión de muerte, sí, pero presentada desde una actitud de entereza y serenidad frente a la existencia y su fatalidad, heredera de aquella otra ya entrevista en nuestro análisis de los primeros poemarios.

En ocasiones, sin embargo, esta nada valentiana adquiere tintes más sombríos, pues nos remite (desde una creciente conciencia de la destrucción y la corrupción) al horror vacui, a la muerte en tanto única realidad para la que el hombre «jamás tendrá un conjuro» (ibid.). Esta sería la tercera y última acepción de la nada, la misma que es definida en «La experiencia abisal» como «nihilidad o nada hueca, negativa» (2004: 203). La presencia de esta última modalidad, la nada nula, es palpable en aquellas composiciones de la primera sección de No amanece el cantor caracterizadas por su retahíla de imágenes que emplazan a la voracidad, la devastación y la muerte. Así, a partir de «Anotación para un fin de siglo» (poema supuestamente anecdótico, en el que la inocente pregunta por la causa de la desaparición de los dinosaurios acaba derivando hacia lo absurdo criminal), los motivos se desmoronan, atrayéndonos hacia 'el espacio de la desolación' e invitándonos a afrontar el «naufragio ideal de la memoria» («[El tiempo se llena de húmedos lagartos...]», 2006: 495) de aquel del que, una vez «No quedan ya residuos de la muerte» («[La filtración aérea de los cuerpos...]», ibid.), emerge aquella «imagen de ti que ni siquiera a ti te pertenece» (ibid.); ese ser que es sólo del olvido, «cuerpo que se confunde con el aire. No tienes nombre, tenuemente borrado, al fin» (ibid.).

El tema de la huella que deja nuestro paso por la vida es recurrente en estos últimos poemarios ${ }^{43}$. Conforme la memoria cede terreno y la muerte se apropia de cada uno, entramos a formar parte (y con nosotros aquellos que nos precedieron y de quienes somos albaceas de su recuerdo) del olvido. Es en este contexto que cobra todo su sentido la última frase de la sección: «¿Quién podría llorarte, muerto, en esta tarde?» («[En el cielo de parís...]», l. c.: 496), que el poeta se dirige a sí mismo, pero que también podemos leer en clave de antesala de la reflexión que protagonizará la segunda sección, «Paisaje con pájaros amarillos», que centrada por entero en la figura del fallecido hijo del

${ }^{43}$ La problemática se refleja en el siguiente fragmento de «[Sube en nosotros...]», de Fragmentos de un libro futuro: «Dime, / ahora que sentado al borde de las aguas / veo pasar la sombra que me lleva, dime, / ¿se irá con ella tu indeleble memoria?» (2006: 560561). Es en este contexto donde, en mi opinión, encuentran lugar las siguientes palabras, en las que asimismo me parece ver una posible motivación para «Paisaje con pájaros amarillos»: «Memoria e inmortalidad son lo mismo, según recuerda Jean-Paul Vernant, para los griegos. [...] Los muertos son los que han perdido la memoria. Pueden aparecerse para pedirnos que honremos su memoria, la memoria de sí que ellos no tienen» (2004: 186). 
poeta, se plantea como un descenso órfico en sentido literal, es decir, una travesía por el territorio de la muerte en la que el canto asume la responsabilidad de ir en busca del ser querido para volverle a la vida.

Así, en «Paisaje...», la comunicación entre el yo y el tú se construye desde ambos lados de una frontera al menos a priori infranqueable: la que separa el mundo de los muertos del de los vivos. De hecho, una de las posibles interpretaciones de la sección radica en considerarla el reverso de aquella intimidad extática antes mencionada: el poeta busca al amado ausente 'dibujado en sus entrañas', si bien esta vez la separación es absolutamente insalvable. Lo constatamos en fragmentos como los que siguen: «Entré en ti [...] y no te hallé. Tú, sin embargo, estabas. No me viste. No teníamos ya señal con que decirnos nuestra mutua presencia. Cruzarse así, solos, sin verse. Pájaros amarillos» — «[Paisaje sumergido...]», 2006: 498-; o «No acudiste a la cita» («[La hora puntual...]», $l$. c.: 497). Además, la memoria juega en contra del poeta y la silueta del hijo se desdibuja progresivamente, tornándose irreconocible: «Yo apenas podía oír tu voz» («[Lentamente...]», ibid.); o «Cuerpo de un desconocido [...]. Ya no quedaba en ti señal alguna que te hiciera nuestro» (l. c.: 497). De ahí que el poeta, en un acto de emotiva sinceridad, no sólo confiese los límites de la palabra poética («Ni la palabra ni el silencio. Nada pudo servirme para que tú vivieras» - $l$. c.: 498-), sino los suyos propios («Yo creí que sabía un nombre tuyo para hacerte venir. No sé o no lo encuentro. Soy yo quien está muerto y ha olvidado, me digo, tu secreto»-ibid.-), en lo que supone el reconocimiento del fracaso de su misión.

Aun así, a lo largo de «Paisaje...», surgen algunos instantes en que cierta luminiscencia asoma por entre las sombras de la desolación («En mis ojos se agolpa repentina la luz. Como si tú, de pronto, volvieras a la vida»-l. $c$.: 497-), lo que nos mostraría otra clave de lectura, esta vez cercana a una resolución positiva del anhelo del poeta, y según la cual el hijo finalmente vivirá en el recuerdo de la propia escritura, de la que ya ha pasado a formar parte. Recordemos que para Valente (que contemplaba la poesía como una «vía de la supervivencia, de la no extinción» — «Bajo un cielo sombrío», 2004: 153-), la palabra poética era «palabra dicha contra la muerte» $(l . c .: 152)$. Lo cierto es que más allá de la preferencia por una u otra interpretación, lo que no deja lugar a dudas es que «Paisaje con pájaros amarillos» supone el instante de máxima tensión en la reflexión sobre la muerte (o lo que viene a ser lo mismo, la vida) de todo el corpus lírico de J. Á. Valente.

La idea de la muerte centra asimismo el desarrollo de Fragmentos de un libro futuro, poema de la aniquilación del yo, pero sobre todo de su anhelo de disolución en la nada ${ }^{44}$. Así, la nostalgia de esta recorre este cuaderno de bitácora del humano tránsito del tiempo hacia la eternidad, y en el que

44 Ya en «Paisaje...» el poeta había expresado el deseo de formar parte del 'giratorio cuerpo' de la nada junto al hijo desaparecido. 
encontramos versos como «y la naturaleza madre me reduce, / me asume en sí, me devuelve a la nada» («El bosque», 2006: 560); o «Y lentamente / entro en el seno inmenso / de ti, la nada. / Cuerpo sólo / solar» («El fuego», l. c.: 578). Se trata ahora, por tanto, de una nada positiva, de ahí que el yo ya no oponga resistencia alguna a la erosión del tiempo («Dejarse vaciar por el tiempo como se dejan vaciar los pequeños crustáceos y moluscos por el mar. El tiempo es como el mar. Nos va gastando hasta que somos transparentes»——Desde el otro costado», l. c.: $551-)^{45}$.

Seres fantasmagóricos, invisibles, «imágenes sin nombre, rostros muertos», «retratos de nadie», el hijo desaparecido, se erigen en los coprotagonistas de la travesía. Una vez más la imposibilidad de la comunicación con aquellos que formaron parte de nuestro pasado, así como los obstáculos que nos impone la memoria, vuelven a impregnar los textos. Pero el poeta conoce de tiempo atrás a la muerte («Me cruzas, muerte, con tu enorme manto / de enredaderas amarillas. // Me miras fijamente. / Desde antiguo / me conoces y yo a ti» - l. c.: 579-), y no olvida que «El fin es el comienzo» («Luces hacia el poniente», $l$. c.: 548) ${ }^{46}$, de ahí el tono elegíaco alejado de patetismo (responsable, por otra parte, de la vigorosa cohesión del poemario), tampoco ajeno a instantes de íntima intensidad vital a partir de lo anecdótico, como el descrito en «Parque de Figueres».

Por otra parte, en Fragmentos... se concentran las diversas estrategias de desubjetivización ya presentes en anteriores poemarios. Así, nos reencontramos con la incapacidad de autorreconocimiento, sea frente al tiempo o el espejo («te has ido transformando en otra cosa / limítrofe de ti, / no tú. / No vuelves / a encontrarte / si regresas a tientas / al cuerpo que tuviste. [...] Depón tu rostro / que ahora desconoces»-«Arco de triunfo», l. $\quad c$. : 555-; «Cuando te veo así, mi cuerpo, tan caído [...] en ti me miro, / igual que un espejo de infinitas imágenes, / sin acertar cuál de entre ellas / somos más tú y yo que las restantes» — «Espejo», l. c.: 580-); el desdoblamiento («Alguien me dice / que un hombre joven viene / de tiempo en tiempo a visitar tu tumba. [...] ¿Quién es esa figura que así acude? // Tal vez eras tú mismo que regresas / para ver dónde está y depositas / al pie de tus cenizas, un ramo / de lluvia o de tristeza» — «El visitante», l. c.: 565-); la desfiguración («Ya no tienes figura»-«Hic locus», l. c.: 571-); la identificación con la nada («Nadie. No estoy. No estás. ¿Volver? No vine nunca» -l. c.: 547-); la fragmentación («De ti no quedan más / que estos fragmentos rotos»——Proyecto de epitafio», l. c.: 552-); e incluso los apócrifos,

\footnotetext{
${ }^{45}$ Para un análisis de mayor profundidad del papel de la temporalidad en Fragmentos..., conviene atender a aquellas composiciones en las que el poeta medita sobre 'el ser del tiempo', concretamente: «Desde el otro costado», «Cero, matriz de lo posible»y «Variación sobre un tema barroco».

46 «Todo comienzo es así postrimería; todo presente, postumidad» se afirma en «El don de ligereza» (2004: 46).
} 
la versión y la anonimia ${ }^{47}$, tal como queda patente en «Anónimo: versión» («Cima del canto. / El ruiseñor y tú / ya sois lo mismo» -l. c.: 582-), breve composición con la que Valente cierra poemario y corpus lírico, y que adquiere pleno sentido a la luz de la siguiente reflexión: «El canto de un ruiseñor, en la Cántiga CIII de Alfonso el Sabio [...] suspende el tiempo y se abre a la eternidad» («En lo más sutil del aire», 2002: 166). También el canto del poeta suspende el tiempo y se abre a la eternidad. Canto sospeso, suspendido: «Oímos la palabra y volvemos el rostro para ver quién la ha dicho y ya no está» («El don de ligereza», 2004: 46).

\section{$A D D E N D A$}

Me ha parecido conveniente dejar fuera de la argumentación el comentario de Palais de Justice, obra narrativa que J. Á. Valente iniciara a mediados de los ochenta y todavía hoy inédita por expresa voluntad suya (excepción hecha de los ocho fragmentos cuya publicación sí fue autorizada), y definida por A. Sánchez Robayna como «cuaderno de prosas narrativas de fondo autobiográfico y de carácter marcadamente "antiargumental" 48》 (2006: 45). Se trata esta vez, a diferencia de El fin de la edad de plata o Nueve enunciaciones, de una narración extensa y cohesionada, «notas profundamente personales relacionadas con su estado de espíritu a raíz de su separación matrimonial» (ibid.). Aun así, en Palais de Justice, Valente, vuelve a experimentar en los confines del género para proponernos una peculiar recreación del material autobiográfico en clave de meditación sobre la alteridad, la identidad y la nada. En cuanto a la alteridad, lo primero que se constata en el texto es que su tratamiento se afronta fundamentalmente desde una óptica del conflicto, tal como podemos observar en este fragmento: «Pretexto, el otro, de lo que no tiene vida de por sí. Venía entonces, como sigue viniendo aún. [...] Irrumpe como disarmonía, preñado de preguntas, ávido de

${ }^{47}$ Particularmente interesante resulta la inclusión por parte de Valente en sus propios poemarios originales de versiones o traducciones (nuestro escritor siempre prefirió la primera denominación) de otros autores (Lautréamont, Artaud, Kafka o Maquiavelo) apenas modificadas. Al respecto, es reveladora la lectura del artículo «Sobre dos poemas de José Ángel Valente», donde A. Sánchez Robayna observa en el citado recurso un signo de desposesión e invisibilidad autorial destinado a privilegiar la doble consideración de la palabra del poema como re-creación infinita y reinscripción en lo anónimo. Complementaria a esta argumentación me parece otra según la cual, a través de estas versiones, Valente estaría poniendo en práctica aquella concepción celaniana del poema como diálogo establecido a través de una 'botella arrojada al mar', «abandonada a la esperanza [...] de que cualquier día, en alguna parte, pueda ser recogida en una playa» (P. Celan, «Discurso de Bremen», 2006: 648) por esa «otra mano [...] cuyo encuentro perfecciona el acto jeroglífico de la escritura» ( $l$. c.: 646).

${ }^{48}$ Atinado adjetivo de nuevo cuño debido, tal como nos recuerda el mismo escritor canario, a Manuel Fernández Rodríguez. 
juzgar, el otro al que nunca podemos responder» (l. c.: 895); así como en «El guardián del fin de los desiertos», relato de naturaleza abierta en el que, bajo la apariencia de ese desdoblamiento del yo en un tú con el que mantiene una relación de recíproca aniquilación, me parece entrever una oscura reflexión acerca de los vínculos entre el escritor y esa otra no menos conflictiva figura de la alteridad que es la escritura ${ }^{49}$.

En tales circunstancias, el escritor vuelve a confiarnos una vez más su concepción crítica del yo, de la identidad:

Fiebre. Combates tú con sucesivas imágenes de ti mismo. Cada una de ellas desea en definitiva fijarte, hacerte decir: soy yo. Pero sólo podrían hacerlo por pura convención. La identidad no es más que una mera convención, el acto innecesario de decir en falso ante cualquiera de las imágenes que sí: soy yo. Una convención en la que creen encontrar existencia infinidad de seres que no son (l. c.: 882).

Así como su percepción de la existencia como vacío, naufragio, disolución: «Se iba desasiendo. Se iba deshaciendo, igual que el humo se deshace. [...] Era como un irse o un desmemoriarse de todo, de todos y de sí. Había llegado la hora, se dijo, del grande y singular naufragio» (l. c.: 885).

Todo ello contribuye a acrecentar uno de los rasgos más definitorios del texto, y que influye de forma directa en el estilo del mismo: me refiero a la recreación de esa atmósfera perturbadora en la que se inscriben los hechos narrados, y en la que alteridad, identidad y nada quedan asociadas a la maquinaria institucional a los pies de la cual se ve ahora arrojado el poeta. Al respecto, Sánchez Robayna anota un detalle importante, que nos ayuda a estimar el enfoque adoptado por Valente a la hora de desgranar el conflicto: «No es dato intrascendente el que una parte del texto original de Palais de Justice venga acompañado, en el mismo cuaderno, por numerosas citas y fragmentos de la obra de Kafka [...], obra en cuya lectura o relectura se hallaba el autor inmerso en ese momento» $(l$. $c .:$ 45-46). Tal vez por ello, cuando lo otro se filtra «bajo las resmas del papel procesal» $(l$. c.: 895), el poeta se ve incapaz de identificar «un tímido fragmento de mi vera existencia» (l. c.: 896) en ese su yo que aparece «en los espesos folios procesales» (ibid.); y devolviéndose a su propio yo de la infancia o la adolescencia (tal vez en demanda de un mínimo asidero para la propia identidad), acabe por declarar con palabras que no hemos dejado de escuchar a lo largo de las diversas páginas de este ensayo: «Todo podría en torno a él caer, desmoro-

${ }^{49}$ Un tratamiento de la alteridad que alcanza momentos de especial brillantez cuando se entremezcla (tal como sucedía en «Paisaje con pájaros amarillos») con la existencia o el recuerdo de personas concretas como primer paso para profundizaciones de signo ontopoético. Así, al hijo desaparecido se unen ahora dos mujeres: una, citada como Madame, identificada con la muerte, y por ello ajena a la belleza y a la alegría; y la otra, descrita en términos de «absoluta negación del morir» $(l$. c.: 893), caracterizada como ese tú donde, a la manera de Mandorla, toman forma las palabras. 
narse, y podría él mismo irse deshaciendo para ya no dejar más que esta sola imagen póstuma de sí» (ibid.).

\section{REFERENCIAS BIBLIOGRÁFICAS SOBRE JOSÉ ÁNGEL VALENTE}

—, «Nuevos maestros», La hora, núm. 23, 8 de abril de 1949, p. 5.

—, «La poesía. Conexiones y recuperación», Cuadernos para el diálogo, núm. extra 23, 1970, pp. 42-44.

—, «Una breve memoria», El País, 18 de mayo de 1987, p. 11.

—, Entrada en materia, Jacques Ancet (ed.), Madrid, Cátedra, 1989.

-, Notas de un simulador, Madrid, La Palma, 1997.

—, Anatomía de la palabra, Nuria Fernández Quesada (ed.), Valencia, Pre-Textos, 2000.

-, Variaciones sobre el pájaro y la red precedido de La piedra y el centro, Barcelona, Tusquets, 2000(a).

—, La voz de José Ángel Valente, Madrid, Publicaciones de la Residencia de Estudiantes, 2001.

—, Elogio del calígrafo, Barcelona, Galaxia Gutemberg-Círculo de Lectores, 2002.

—, Las palabras de la tribu, Barcelona, Tusquets, 2002(a).

—, La experiencia abisal, Barcelona, Galaxia Gutemberg-Círculo de Lectores, 2004.

-, Obras completas I. Poesía y prosa, Andrés Sánchez Robayna (ed.), Barcelona, Galaxia Gutemberg-Círculo de Lectores, 2006.

Fecha de recepción: 18 de diciembre de 2006

Fecha de aceptación: 12 de febrero de 2008 